\title{
Insight into the development of a carbonate platform through a multi-disciplinary approach: a case study from the Upper Devonian slope deposits of Mount Freikofel (Carnic Alps, Austria/Italy)
}

\author{
Damien Pas • Anne-Christine Da Silva - Thomas Suttner • \\ Erika Kido • Pierre Bultynck • Monica Pondrelli • Carlo Corradini • \\ David De Vleeschouwer · Claudia Dojen · Frédéric Boulvain
}

Received: 26 July 2013/Accepted: 6 October 2013/Published online: 23 November 2013

(c) Springer-Verlag Berlin Heidelberg 2013

\begin{abstract}
The development and behavior of million yearscaled depositional sequences recorded within Palaeozoic carbonate platform has remained poorly examined. Therefore, the understanding of palaeoenvironmental changes that occur in geological past is still limited. We herein undertake a multi-disciplinary approach (sedimentology, conodont biostratigraphy, magnetic susceptibility (MS), and geochemistry) of a long-term succession in the Carnic Alps, which offers new insights into the peculiar evolution of one of the best example of Palaeozoic carbonate platform
\end{abstract}

D. Pas $(\varangle) \cdot$ A.-C. Da Silva · F. Boulvain

Sedimentary Petrology, B20, University of Liège (ULg),

Sart-Tilman, 4000 Liège, Belgium

e-mail: dpas@ulg.ac.be

T. Suttner $\cdot$ E. Kido

Institute for Earth Sciences (Geology and Paleontology),

University of Graz, Heinrichstrasse 26, 8010 Graz, Austria

P. Bultynck

Department of Paleontology, Royal Belgian Institute of Natural

Sciences, Rue Vautier 29, 1000 Brussels, Belgium

\section{Pondrelli}

Dipartimento di Ingegneria e Geologia, International Research

School of Planetary Sciences, Università d'Annunzio, viale

Pindaro 42, 65127 Pescara, Italy

C. Corradini

Dipartimento di Scienze Chimiche e Geologiche,

Università di Cagliari, via Trentino 51, 09127 Cagliari, Italy

D. De Vleeschouwer

Earth System Science, Vrije Universiteit Brussel,

Pleinlaan 2, 1050 Brussels, Belgium

C. Dojen

Landesmuseum für Kärnten, Museumsgasse 2,

9021 Klagenfurt, Austria in Europe. The Freikofel section, located in the central part of the Carnic Alps, represents an outstanding succession in a fore-reef setting, extending from the Latest Givetian (indet. falsiovalis conodont zones) to the Early Famennian (Lower crepida conodont zone). Sedimentological analysis allowed to propose a sedimentary model dominated by distal slope and fore-reef-slope deposits. The most distal setting is characterized by an autochthonous pelagic sedimentation showing local occurrence of thin-bedded turbiditic deposits. In the fore-reef slope, in a more proximal setting, there is an accumulation of various autochthonous and allochthonous fine- to coarse-grained sediments originated from the interplay of gravity-flow currents derived from the shallow-water and deepwater area. The temporal evolution of microfacies in the Freikofel section evolves in two main steps corresponding to the Freikofel (Unit 1) and the Pal (Unit 2) limestones. Distal slope to fore-reef lithologies and associate changes are from base to top of the section: (U1) thick bedded litho- and bioclastic breccia beds with local fining upward sequence and fine-grained mudstone intercalations corresponding, in the fore-reef setting, to the dismantlement of the Eifelian-Frasnian carbonate platform during the Early to Late Frasnian time (falsiovalis to rhenana superzones) with one of the causes being the Late Givetian major rift pulse; (U2) occurrence of thinbedded red nodular and cephalopod-bearing limestones with local lithoclastic grainstone intercalations corresponding to a significant deepening of the area and the progressive withdrawal of sedimentary influxes toward the basin, in relation with Late Frasnian sea-level rise. MS and geochemical analyses were also performed along the Freikofel section and demonstrate the inherent parallel link existing between variation in MS values and proxy for terrestrial input. Interpretation of MS in terms of palaeoenvironmental processes reflects that even though distality 
remains the major parameter influencing MS values, carbonate production and water agitation also play an important role.

Keywords Carbonate platform · Cellon-Kellerwand Nappe - Magnetic susceptibility · Geochemistry · Stable carbon isotope $\cdot$ Mid-Late Devonian

\section{Introduction}

The Carnic Alps represent one of few places within the alpine range where an almost continuous sedimentary record from the Ordovician to the Permo-Carboniferous is preserved. One of the largest Devonian carbonate complexes known in Europe is exposed in the central part of the mountain chain. This extended carbonate complex has been the focus of many researcher dealing with taxonomy, stratigraphy, sedimentology, and geochemistry, e.g., of von Gaertner (1931), Walliser (1964), Bandel (1969, 1972, 1974), Pölsler (1969a, b), Schönlaub (1971, 1980), Pohler (1982), Galli (1985), Kreutzer (1989), Oeckentorp-Küster and Oeckentorp (1992), Joachimski et al. (1994), Perri and Spalletta (1998), Schönlaub and Histon (2000), Schönlaub et al. (2004), Hüneke (2006, 2007), Hubmann and Suttner (2007), Suttner (2007), Corradini and Corriga (2010, 2012), and Corradini et al. (2012). According to Kreutzer (1992a, b) and Schönlaub (1992), Devonian reefs of the Carnic Alps had their climax during the Givetian and Early Frasnian prior to decline within the Late Frasnian. Coral and stromatoporoid patch reefs already started to produce a several hundred-meter-thick carbonate platform during the Early Devonian (Suttner 2007). In general, Devonian deposits of the Carnic Alps are divided into five S-SE to N-NE-directed facies belts: (1) southern shallow-water facies; (2) transitional facies; (3) pelagic limestone facies; (4) offshore, pelagic basinal facies; and (5) northern shallow-water facies. The reef-related sedimentation took place within a differently subsiding basin during a period of extensional regime. This was highlighted by significant variation in carbonate thickness of about one thousand meters occurring between the shallow-water (belt 1) and the pelagic (belt 3) facies. Between these two facies belts, a transitional environment with varying thickness, corresponding to the facies belt 2, was developed. More than thirteen microfacies types were identified by Kreutzer (1990, 1992a, b) discriminating all the different lithologies occurring during the Lochkovian to Frasnian interval.

Although Middle and Upper Devonian deposits of the Carnic Alps have been studied since the second half of the nineteenth century, a lot of uncertainties remain regarding the size and evolution of the Devonian platform. Geometrical complexity resulting from the Variscan and Alpine orogenies, hardly accessible outcrops, and lack of a precise biostratigraphic control within the shallow-water setting have slowed down further palaeoenvironmental investigations and therefore our knowledge about the evolution of life on Earth. In order to get a better understanding of the Devonian platform/basin evolution, including a reliable stratigraphical framework, we need new data within the socalled transitional facies defined by Kreutzer (1990). As indicated by their name, these "transitional" facies closely connect the shallow with the open-sea facies, and despite the possible reworking occurring in this setting (occurrence of breccias), they are datable by conodonts as the standard biozone sequence remains undisturbed (e.g., Spalletta et al. 1983). Therefore, biostratigraphic studies based on conodont from the "transitional" facies could bring a considerable improvement in deciphering the age of the shallow-water units. A remarkable succession recorded within those "transitional" facies is well exposed and preserved at Mount Freikofel (Austria/Italy border). In this paper, we document a detailed sedimentological study of the continuous Latest Givetian-Early Famennian succession (Freikofel Limestone and Pal Limestone) observed in the upper part of the Freikofel section in order to provide a detailed analysis and illustration of the Upper Devonian "transitional" and pelagic facies within the Carnic Alps. We present a new dataset including conodont biostratigraphy, geochemistry (major and trace element analysis and $\delta^{13} \mathrm{C}$ stable isotopes), and magnetic susceptibility (MS) analyses in order to gain a better understanding of the depositional and environmental changes in a fore-reef setting within the Carnic Alps. Moreover, the biostratigraphic control of the succession offers the first opportunity to establish a reliable timing for the reworking and demise/drowning of the reefal structure within the Cellon-Kellerwand Nappe. Therefore, it allows to improve our knowledge of global changes over a long timescale in Palaeozoic. Geochemistry and MS measurements taken on the Freikofel succession in the fore-reef setting might help to establish further correlation between Upper Devonian transitional lithologies throughout the Carnic Alps and elsewhere.

\section{Location and geological context}

The Carnic Alps are situated at the southern margin of the European Variscides and belong to an east-west striking South Alpine domain of the Alps, extending across the ItalyAustrian border. The pre-Variscan sequence of the Carnic Alps is composed of an almost continuous sequence of sedimentary rocks ranging from Ordovician to Late-Early Carboniferous (compare Austrian Stratigraphic Chart of Piller et al. 2004; Hubmann et al. 2013) and belongs to the "Proto Alps" depositional basin north of Gondwana (Schönlaub and 
Fig. 1 Palaeogeographical reconstruction showing the location of the Carnic Alps during the Middle Devonian (modified after Scotese 2002)

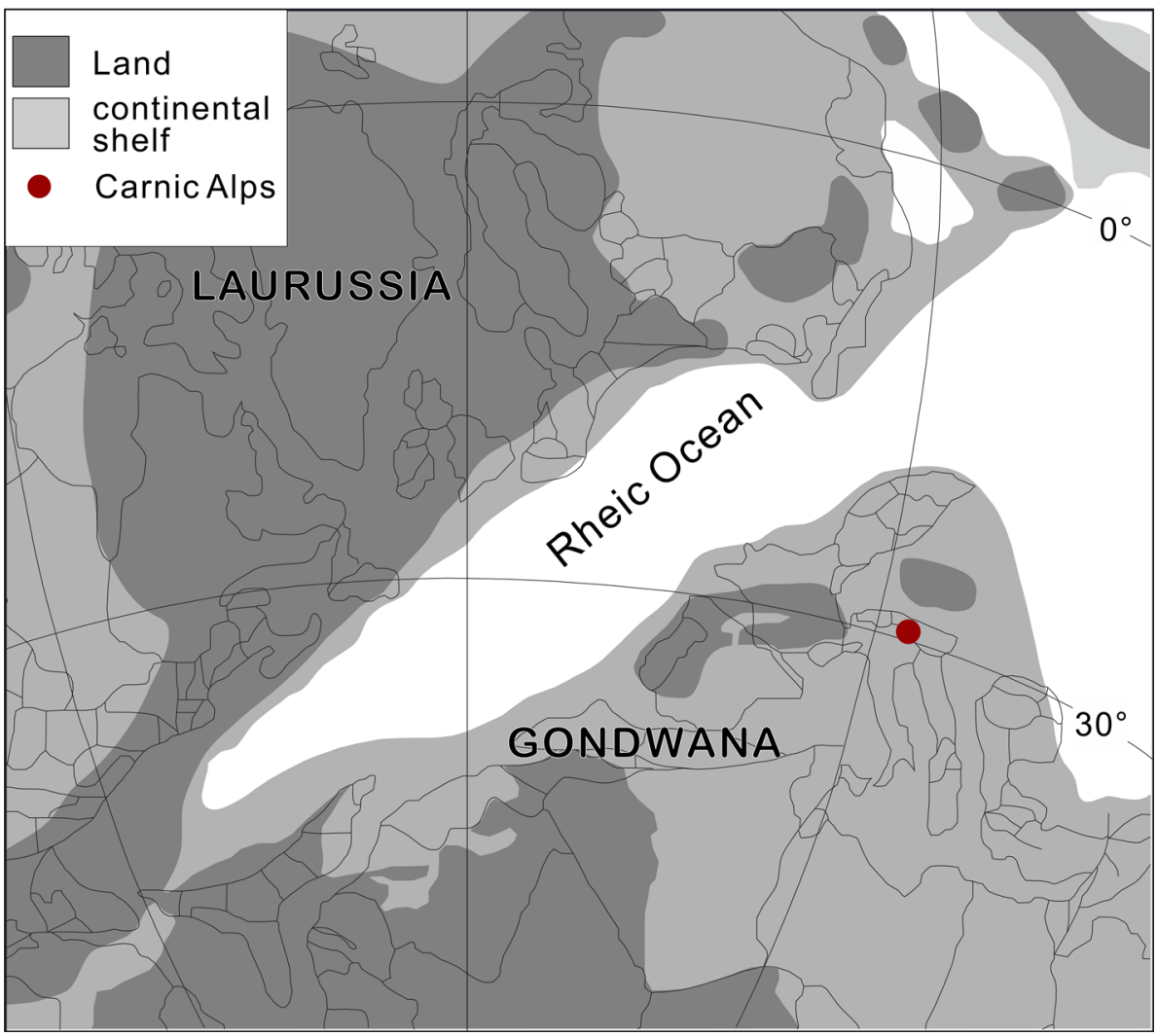

Histon 2000) (Fig. 1). Overlying the Variscan sequence, Late Carboniferous to Triassic units (post-Variscan Sequence) were deposited. Post-Variscan sequence consists of non- to low-metamorphic substratum of the following Alpine cycle (Vai 1975). The entire Palaeozoic sequence was subjected to both Variscan and Alpine orogenies. Both orogenies resulted in the formation of several thrust sheets, imbricate nappe systems, and dislocations. The Variscan orogeny is interpreted as formed at considerable crustal depth, which leads to more ductile deformations, including recumbent folding (Venturini 1990; Brime et al. 2008). The resultant structural setting has been sketched by Läufer et al. (2001) who defined four major tectonic units (Fig. 2). From west to east, they are, respectively, named Late Alpine transpressive blocks, Fleons Nappe, Cellon-Kellerwand Nappe, and the Hochwipfel Nappe. These four tectonic units differ from each other in regard to their stratigraphy, grade of metamorphism, and deformation. In the Cellon-Kellerwand Nappe (Fig. 2), an almost continuous sedimentary record extending from the Late Ordovician to the Early Carboniferous with low-grade metamorphism and several tectonic deformations are revealed. This succession is mainly calcareous but includes shallow- to deepwater siliciclastic deposits. Starting from the Early Devonian, a reef complex and associated facies, encompassing all facies belts ranging from shallow-water to off-reef basinal facies, are exposed within the Cellon-Kellerwand Nappe (Bandel 1974; Vai 1975; Schönlaub 1979,
1985; Kreutzer 1992b). The significant reef development in the area is remarkably shown by the thickness ratio of 12:1 between shallow-water sedimentary pile and the contemporary pelagic cephalopod limestone deposits (Kreutzer 1989). It ended during the Frasnian Upper rhenana Zone (=Upper gigas Zone; Kreutzer 1990), following a general transgression possibly caused or enhanced by local extensional tectonics (Spalletta and Vai 1984).

According to regional settings, the fore-reef area consists of massive limestone including reefal debris and lithoclasts (Cellon Limestone), which gradually changes toward the east into bedded allodapic limestone (Freikofel Limestone). Both units are overlain by pelagic cephalopod limestone (Pal Limestone). The geographical distribution of the transitional facies related to the Freikofel Limestone can be traced from Mount Kleiner Pal (Schönlaub 1991: p. 39) toward east, with best outcrops at Mount Freikofel (Lischka 2007; Stark 2007; Schnellbächer 2007, 2010a, b) and Pramosio area (Spalletta and Perri 1998). According to geological maps (Schönlaub 1991), deposition of transitional facies initiated somewhere between Mount Cellon and Mount Kleiner Pal. On the Mount Cellon, the Cellon Limestone is directly overlain by the Pal Limestone lacking deposits characteristic for the Freikofel Limestone. According to Austrian authors (Piller et al. 2004), a summary of the Devonian stratigraphy of the Cellon-Kellerwand Nappe with the location of the Freikofel section is 


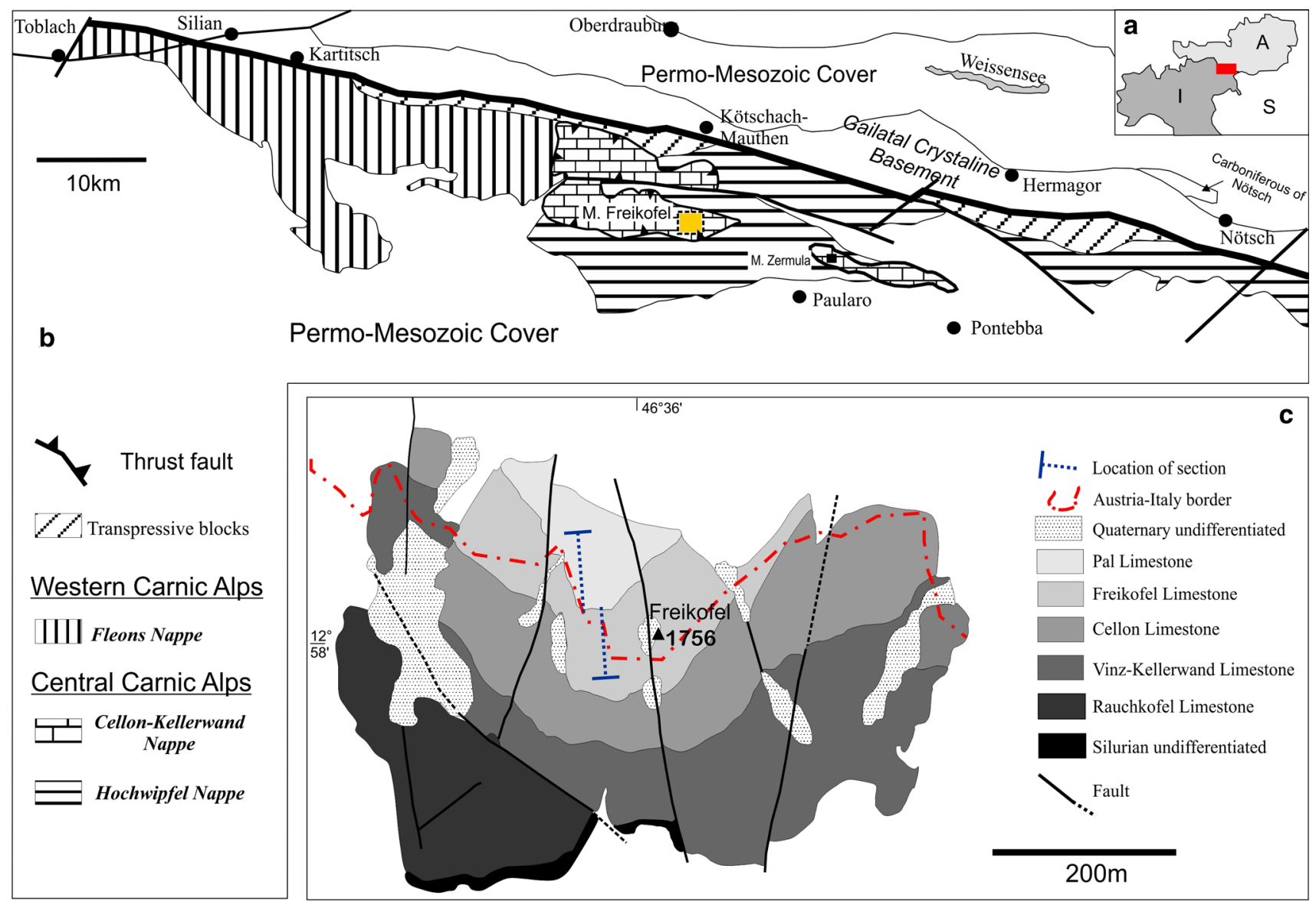

Fig. 2 a Location of the Carnic Alps area at the Austria-Italy border. b Location of Mount Freikofel in the carnic chain (redraw from Läufer et al. 2001). c Simplified geological map of Mount Freikofel with location of the studied sections (modified from M. Pondrelli, unpublished)

Fig. 3 General stratigraphic scheme and facies relationship of Devonian units in the Carnic Alps according to Austrian authors (Piller et al. 2004). Modifications are made for the Freikofel Limestone according to its age and relation with the cellon limestone (red dotted line) based on the age range mentioned in Brime et al. (2008), on the geological map of Venturini et al. (2009), and the new conodont data obtained for this study

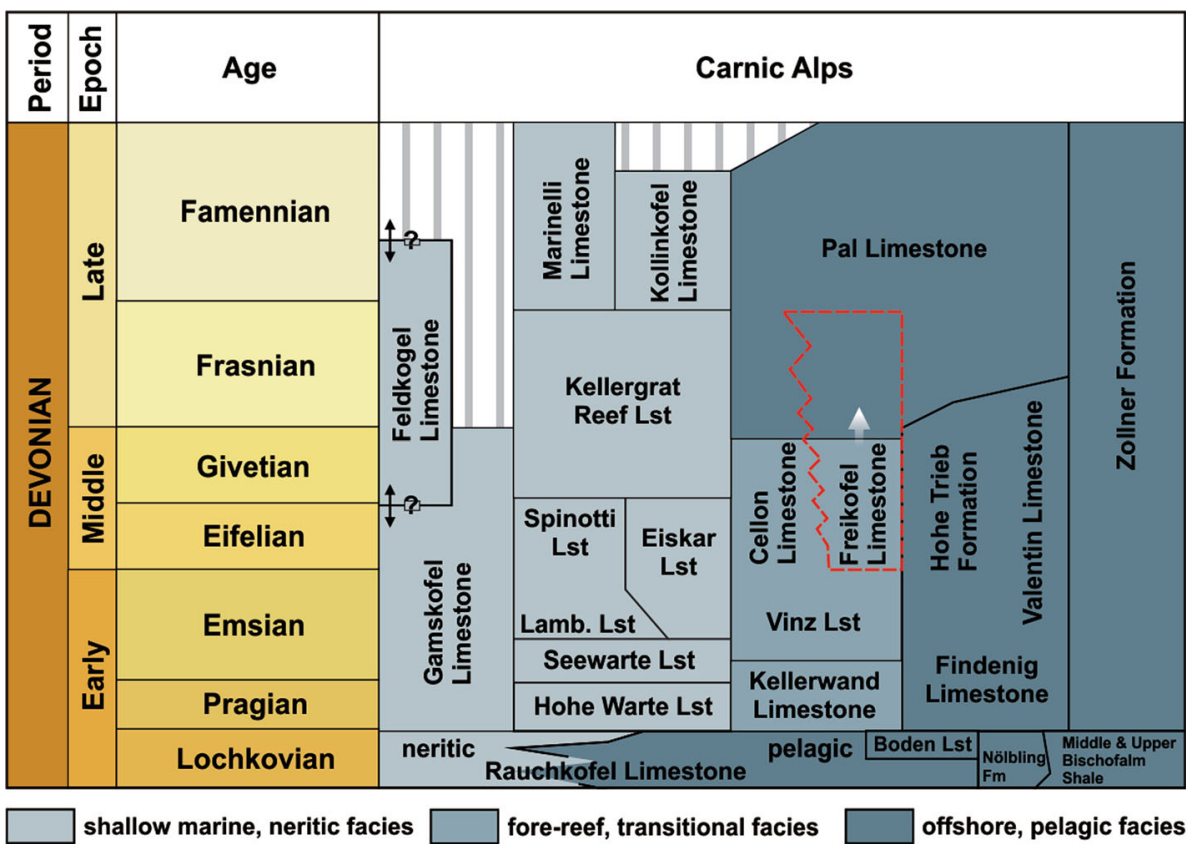


illustrated in the Fig. 3. In the Italian literature (i.e., Venturini et al. 2009), a stratigraphic unit named "Calciruditi del Freikofel" ranging from Pragian to Famennian is described but, it has to be mentioned that this unit has a different meaning of the Freikofel Limestone as used in this paper. Therefore, comparison between Austrian and Italian stratigraphic units is not straightforward.

\section{Methods}

A detailed bed-by-bed description and sampling of the Freikofel sections (Figs. 4, 6) were performed with an average sampling rate of one sample per $20 \mathrm{cms}$ (except for the massive breccia levels where the sampling rate is one sample per meter). For microfacies analysis, 200 samples were collected. The textural classification used to characterize the microfacies follows Dunham (1962) and Embry and Klovan (1972). Estimation of sorting is based on the visual charts of Pettijohn et al. (1972). Thin sections were stained using Dickson solution to differentiate calcite, dolomite, feroan calcite, and feroan dolomite (Dickson 1965). Eighteen samples $( \pm 400 \mathrm{gr})$ belonging to intermediate slope and pelagic facies were taken for conodont investigation. Conodont frequency is poor to good, depending of the facies (from 10 to 50 specimens $/ \mathrm{kg}$ ). Thin sections and conodont samples are stored in the sedimentary petrology building (B20, University of Liège). Analyses of $\delta^{13} \mathrm{C}_{\text {carb }}$ were done on 35 samples collected around the proposed FrasnianFamennian boundary interval using bulk mudstone-wackestone. Powdered samples reacted with phosphoric acid in an online carbonate preparation (Kiel III carbonate device) connected to a Thermo-Delta plus XL mass spectrometry instrument at the Vrij Universiteit Brussel, Belgium. Samples were calibrated to the NBS19 standard $\left(\delta^{13} \mathrm{C}=1.95\right.$ promille VPDB). MS measurements were undertaken on more than 200 rock samples. Each sample was analyzed three times with KLY-3 (Kappabridge) and weighed with a precision of $0.01 \mathrm{~g}$. This allows the definition of the masscalibrated MS for each sample and the construction of MS plots. Major and trace elements were measured using X-ray Fluorescence (ARL 9400 XP XRF instrument, University of Liège) on 15 samples regularly spaced through the studied part of the Freikofel section. The analyzed rock samples were carefully cleaned prior to all treatment: weathered surfaces were removed. The major elements (in this paper, $\mathrm{SiO}_{2}, \mathrm{TiO}_{2}, \mathrm{~K}_{2} \mathrm{O}$, and $\mathrm{Al}_{2} \mathrm{O}_{3}$ ) were analyzed on lithium tetraand meta-borate-fused glass discs, with matrix corrections following the Traill-Lachance algorithm and are expressed in elemental oxide concentration. Trace elements (in this paper, $\mathrm{Zr}, \mathrm{Cu}, \mathrm{Ni}$, and $\mathrm{Sr}$ ) were measured on pressed powder pellets, and data were corrected for matrix effects by Compton peak monitoring and expressed in elemental concentration. Precision and accuracy were both shown to be better than $1 \%$ for major elements and $5 \%$ for trace elements as proved by international standards and analyses of replicate samples, respectively.

\section{Results}

Description of section

The outcrop exposed at Mount Freikofel $\left(46^{\circ} 36^{\prime} 05.2^{\prime \prime} \mathrm{N}\right.$, $\left.12^{\circ} 58^{\prime} 37.1^{\prime \prime} \mathrm{E}\right)$ provides a stratigraphically continuous succession of strata, which starts within the Lochkovian and ends during the Lower Famennian. The entire section encompasses six formations: Rauchkofel, Kellerwand, Vinz, Cellon, Freikofel, and Pal Limestones (Figs. 3, 4). For the purpose of this investigation, we focused on the upper part of the Freikofel section including the upper part of the Freikofel Limestone and the base of the overlying Pal Limestone. The measured section is continuous, about 62 meters thick (Figs. 5, 6), and covers a stratigraphic interval extending from the Latest Givetian-Early Frasnian to Early Famennian. The measured succession of strata is oriented $\mathrm{N} 110^{\circ} \mathrm{E}$ with an average dip of $52^{\circ} \mathrm{NE}$. Strata usually show a strongly weathered surface, a covering by lichens and in the lower part a massive aspect. Despite those limiting factors, the main lithostratigraphic units have been recognized and mapped (Fig. 2).

Description of the lithological units

\section{Unit 1 ( 32.5 m-thick, upper portion of the Freikofel} Limestone; Fig. 4)

This lower portion of the measured section mainly consists of several-m-thick (Fig. 4b) gray to blue beds of coarsegrained lithoclastic and bioclastic limestones locally intercalated by $\mathrm{dm}$ to several-dm-thick limestone beds. Lithoclasts are commonly sub-angular to rounded, $\mathrm{cm}$ to several tens-cm-sized (Fig. 4c, d). They are loosely to densely packed, are moderately sorted and of various color; some are dark gray in color, similar to the matrix. Where the texture is not concealed by alteration and/or lichens, a fining upward grading of lithoclasts is observed. Bioclasts are scarce, $\mathrm{cm}$ to $\mathrm{dm}$ in size, and mainly represented by stromatoporoid, crinoid and tabulate, and rugose coral fragments. Through the upper part of Unit 1, the thickness of beds decreases.

Unit 2 ( 29.5 m-thick, lower and middle portions of the Pal Limestone; see Fig. 4)

The boundary between the Freikofel and the Pal Limestones is defined by the predominance of mudstone over 

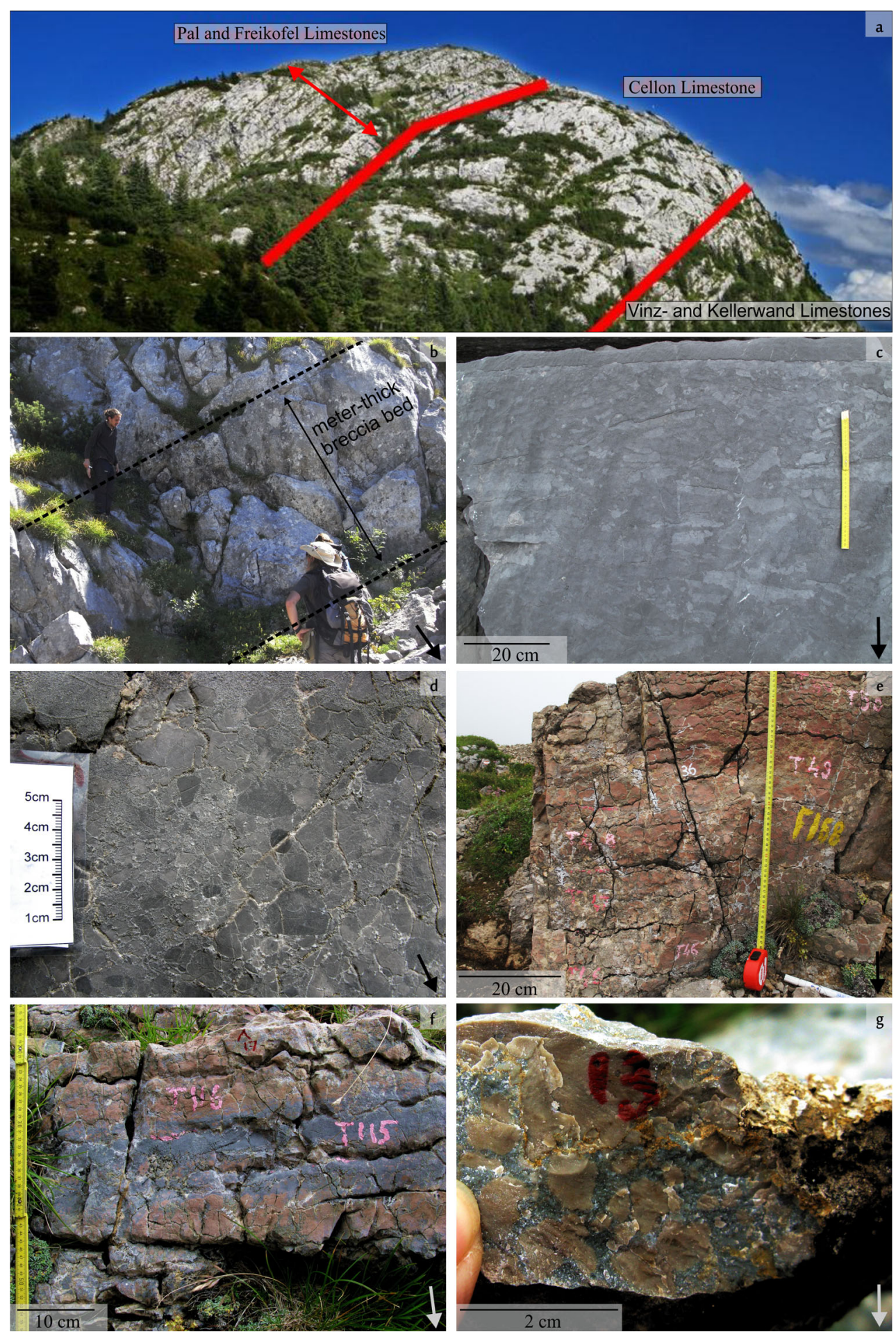

Fig. 4 a View of Mount Freikofel showing the studied interval (Freikofel Limestone and Pal Limestone; view from the west) and the underlying Cellon Limestone and undifferentiated Vinz and Kellerwand Limestones. b Several-m-thick breccia bed belonging to the Freikofel Limestone. Dashed lines indicate the bedding plan. c Closeup on a breccia bed with well-visible light gray elongated lithoclasts (MF6). d Close-up on a breccia levels exposing different types of sub- rounded lithoclasts. e Thin-bedded red to pink nodular limestone characterizing the Pal Limestone. f Pink to red thin-bedded limestone showing blue gray coarse-grained limestone horizon (MF3). g Closeup on a coarse-grained limestone intercalation (MF3) showing wellvisible infra-centimeter reddish lithoclasts from the underlying thinbedded limestone (MF1). The arrow on the lower right of the pictures points to the stratigraphic base 
grainstone facies. Unit 2 corresponds mainly to a succession of thin-bedded several-cm to tens of $\mathrm{cm}$-thick grayish, pinkish to reddish fine-grained burrow-mottled limestone with numerous stylolite-like structures along the stratification planes (Fig. 4e). These fine-grained limestones correspond to the so-called Flaserkalk of Bandel (1974). A particular character of Unit 2 is the common occurrence in these fine-grained sediments of two different types of coarser-grained limestone levels: (1) $\mathrm{cm}$ to several-cmthick bluish grainstone horizons showing locally well-visible infra-cm reddish lithoclasts (Fig. $4 \mathrm{~g}$ ) and (2) several$\mathrm{dm}$ to $\mathrm{m}$-thick beds showing several-cm-sized lithoclasts of various lithologies locally displaying a fining upward grading. In the first case, lateral continuity of intercalation can be followed for several tens of meters.

Bio- and chemostratigraphy

In order to provide a biostratigraphic framework for the microfacies/sedimentology works performed on the Freikofel section, we selected 18 samples from the "transitional" (Freikofel Limestone) and the pelagic facies (Pal Limestone) for conodont analysis. They reveal a stratigraphic interval ranging from the Latest Givetian to Early Famennian. The occurrence of Mesotaxis falsiovalis and Polygnathus dubius near the base of the section (sample: FK93b) indicates a Latest Givetian age and constrains the sampled bed to an interval ranging from the Lower falsiovalis (FAD: Mesotaxis falsiovalis) or transitans zone (LAD: Polygnathus dubius). A 2-meter-thick interval near the 10-m-mark yields P1 elements of Ozarkodina trepta (samples: FK82a, b; FK83; FK85a, b and FK86), which indicate the Lower hassi zone. The occurrence of Palmatolepis rotunda (sample: FK62') and Pa. aff. subrecta (sample: FKS22-28) around the 40-m-mark documents the Late Frasnian age as the total range of both taxa is constricted from the Early-Late rhenana zone until late in the linguiformis zone. Sample FKS74 from the lower part of the Pal Limestone yields in addition to Late Frasnian conodont elements like Palmatolepis rotunda elements of Polygnathus timorensis, which indicate reworking of Givetian deposits from the platform at least until the Late Frasnian. P1 elements identified as Palmatolepis cf. crepida (sample: FK07) near the top of the section document the upper limit of the sequence at Mount Freikofel within the crepida Zone (indet. zonation). Some diagnostic Middle and Late Devonian conodont elements are illustrated in Fig. 5. Furthermore, a distinctive positive shift of about 3 promille in the $\delta^{13} \mathrm{C}$ trend is related to the Upper Kellwasser event and indicates the Frasnian-Famennian boundary in the section (Fig. 6b).
Microfacies

MF1: bioturbated microbioclastic mudstone-wackestone (Fig. 7a-f)

This microfacies mostly occurs in the uppermost part of the section between 41 and $60 \mathrm{~m}$ (Unit 2) and consists of grayish to red thin-bedded limestone (Fig. $4 \mathrm{e}-\mathrm{f}$ ). It is mostly characterized by the occurrence of pelagic/hemipelagic microfossils such as thin-shelled bivalves, goniatites (Fig. 7a), entomozoan ostracods, styliolinids, and trilobites. These fossils are scattered in a dark brown micritic matrix and are commonly associated with unidentifiable filaments and sponge spicules (Fig. 7d). A significant characteristic of this microfacies is bioturbation (Fig. 7bc), which is locally intense and show lighter color compared to the non-disturbed surrounding sediments and lower amount in bioclasts. Rarely, burrows filled with grainstone (corresponding to MF3) occur. Another particular character of this microfacies is the local intercalation of several-mm to several-cm-thick layers of well-sorted lithoclastic grainstone (Fig. 7e) with lower sharp erosional boundary (Fig. 7f) and fining upward grading. Locally inverse grading with erosive base also occurs. Mottled nodular structures are frequent and highlighted by reddishbrown Fe oxides envelopes. Locally, an iden-supported fabric is very well exposed.

\section{Interpretation}

In numerous sedimentological studies (Rabien 1956; Tucker 1973; Vai 1980; Wendt and Aigner 1985; Pas et al. 2013; Königshof et al. 2012), the Devonian thinbedded cephalopod limestone in Europe has been interpreted as being accumulated upon submarine rises at depths reaching several tens to about one hundred meters. Wendt and Aigner (1985) also suggested that thin-bedded cephalopod limestones were probably formed during times of reduced sedimentation rate. Indeed, the common occurrence of bioturbation likely indicates low accumulation rate, as well as oxygenated bottom water (Flügel 2004). The predominance of deepwater fossils attests an hemipelagic/pelagic environmental setting. Furthermore, the very fine-grained sediment of this microfacies points to a low energy setting located below the storm wave base (SWB) where the main sedimentary process is the product of settling of a very fine turbid tail and of periplatform oozes. This microfacies was thus deposited in a distal slope setting oxygenated environment with a low accumulation rate episodically influenced by distal turbidites (see MF3 below). 


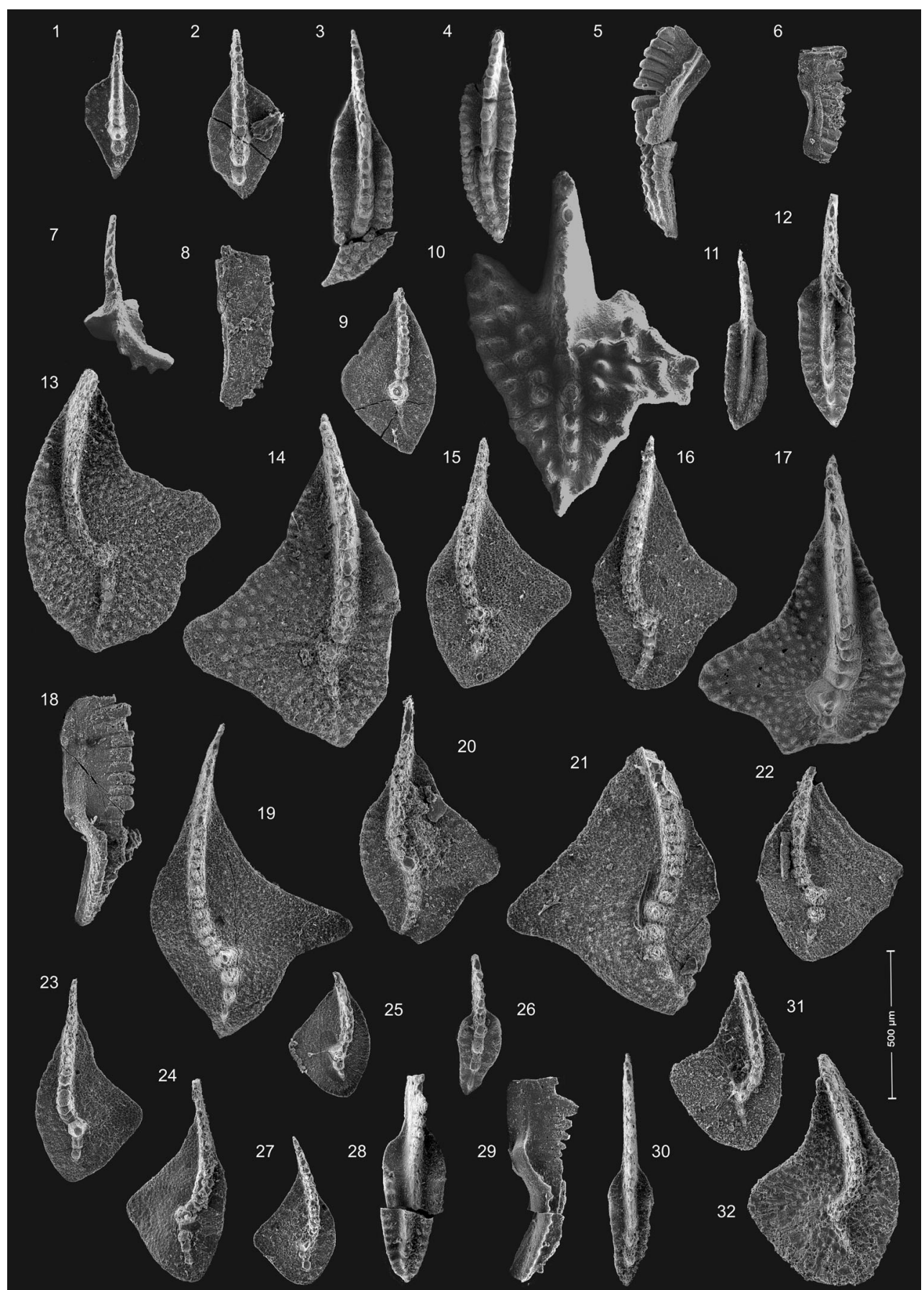

MF2: fine-grained bioclastic styliolinid wackestone-packstone (Fig. 7h)

This microfacies is mainly observed within Unit 1 either as decimeter-sized interbeds or as constituting part of the $\mathrm{m}$-thick breccia beds (see description of Unit 1). This microfacies also occurs as lithoclasts within the MF6, or with MF4 through vertical grading. Locally, lenticular grainstone texture (corresponding to MF5) occurs within this wackestone-packstone (Fig. 7g). Styliolinids (average size around $0.05 \mathrm{~mm}$ diameter) are generally disseminated but locally concentrated in styliolinid wackestone to packstone lenses (Fig. 7h). From time to time, a well-preserved fining upward grading from MF2 toward MF1, followed by bioturbated MF1, is also observed. Other significant characteristics of MF2 are the finely broken character of allochems (average size: $0.15 \mathrm{~mm}$ ), which make most of them unidentifiable, and the dominance of pelagic 
4 Fig. 5 Some important conodonts of the Freikofel section. 1 Mesotaxis falsiovalis, oral view of P1 element from FK93b. 2 Mesotaxis falsiovalis, oral view of P1 element from FK93b. 3 Polygnathus dubius, upper view of $\mathrm{P} 1$ element from FK93b. 4 Polygnathus dubius, upper view of P1 element from FK93b. 5 Polygnathus dubius, lateral view of P1 element from FK93b. 6 Tortodus intermedius, oral view of P1 element from FK93b. 7 Ozarkodina trepta, upper view of P1 element from FK85a. 8 Ozarkodinia bidentata, lateral view of P1 element from FK93b. 9 Palmatolepis sp., oral view of a juvenile P1 element from FK93b. 10 Ancyrodella lobata, upper view of P1 element from FK87b. 11 Polygnathus xylus, upper view of P1 element from FK93b. 12 Polygnathus dubius, upper view of P1 element from FK81. 13 Palmatolepis rotunda, upper view of P1 element from FK62'. 14 Palmatolepis hassi, non-adult specimen, upper view of P1 element from FK62' 15 Palmatolepis aff. hassi, upper view of $\mathrm{P} 1$ element from FK62'. 16 Palamtolepis aff. hassi, upper view of P1 element from FK62' 17 Palamtolepis cf. hassi, upper view of the P1 element from FK50. 18 Polygnathus decorosus, lateral view of P1 element from FK50. 19 Palmatolepis nasuta, upper view of P1 element from FK50. 20 Palmatolepis hassi, upper view of the P1 element from FK50. 21 Palamtolepis hassi, upper view of P1 element from FK46a. 22 Palmatolepis cf. gigas, upper view of P1 element from FK07. 23 Palmatolepis aff. subrecta, non-adult specimen, upper view of P1 element from FK07. 24 Palmatolepis aff. subrecta, upper view of P1 element from FKS22-28. 25 Palmatolepis sp., juvenile specimen upper view of P1 element from FKS22-28. 26 Polygnathus sp., juvenile specimen, upper view of P1 element from FKS74. 27 Palmatolepis delicatula, upper view of P1 element from FK07. 28 Polygnathus decorosus, upper view of P1 element from FKS98. 29: Polygnathus decorosus lateral view of P1 element from FKS74. 30 Polygnathus aff. timorensis, upper view from P1 element from FKS96-98. 31 Palmatolepis rotunda, upper view of P1 element from FKS74. 32 Palmatolepis rotunda, upper view of P1 element from FKS96-98

organisms over shallow-water ones. Recognized organisms are infra-millimeter in size and in order to the abundance represented by styliolinids, crinoids, thin-shelled bivalves, calcispheres, ostracods, entomozoacean ostracods, and trilobites. The sorting of this sediment is moderate to good and bioturbations occur.

\section{Interpretation}

The common to abundant occurrence of styliolinid shells and finely broken bioclasts in micritic matrix points to a hemipelagic depositional setting where the prominent sedimentary process is the periplatform oozes settling. Even if locally styliolinid shells are the dominant biogenic components and thus represent the background sedimentation, the common association with finely broken unidentifiable bioclasts is thought to reflect a mixture with materials derived from shallower marine realms. This mixture of biota from different origin can be explained by a winnowing of the sediment during more turbulent events such as gravity flow or storm. The well-preserved fining upward grading MF2 toward MF1, followed by bioturbated MF1, points to a turbiditic origin of these sequences; MF2MF1 corresponds to the final sedimentation step recognized in the Bouma sequence (Td-Te interval of Bouma). Indeed, ideal turbiditic sequence of Bouma (1962), Piper (1978) and Stow and Shanmugam (1980) usually shows a final phase of sedimentation with a fining upward succession ending with bioturbated pelagic fine sediment. The common occurrence of MF2 lithoclasts within rudstone texture of MF6 (see below) indicates a depositional setting influenced by temporarily strong bottom current such as gravity flow. The local occurrence of MF2 in the top of meter thick fining upward sequences occurring in the breccia beds of Unit 1 also supports our interpretation.

\section{MF3: lithoclastic grainstone (Fig. 7e-f)}

This microfacies only occurs in Unit 2 as $\mathrm{mm}$ - to $\mathrm{cm}$-sized lithoclastic grainstone intercalation within the mudstonewackestone beds of MF1 (Figs. 5f, 7e). The cement of this grainstone is a sparite. Where outcrop conditions are good, it is possible to follow these intercalations laterally for several tens of meters. Where the pressure solution processes does not affect the sediment, the lower boundary of these grainstone layers appears sharp and with erosional contact, with scours and fills (Fig. 7e-f). Lithoclasts are mostly well-rounded even if some are angular, relatively well-sorted (locally bimodal) and their size ranges from 0.5 to $2 \mathrm{~mm}$. Fining upward grading occurs locally (Fig. 8a). The lithoclasts are composed of mudstone and wackestone textures, respectively, corresponding to MF1 or MF2. Lithoclasts are associated with crinoid fragments and less frequent bioclasts such as brachiopods, ostracods, and stromatoporoids.

\section{Interpretation}

The intercalation of this thin-bedded lithoclastic grainstone (MF3) horizons within the hemipelagic/pelagic setting (MF1), the abundance of lithoclasts, their relatively good sorting, the fining upward, and the lateral persistence of the layers are diagnostic features of distal slope thin-bedded turbiditic deposits (Mutti 1977; Flügel 2004). According to Mutti (1977), thin-bedded turbiditic deposits are the product of waning and relatively dilute turbidity currents that carry fine-grained sand and silt-sized particles. According to Flügel (2004), the absence of shells concentration and flat top/base as well as the presence of grading allow to exclude an accumulation by distal tempestites. This MF3 corresponds to the "redeposited beds" occurring in pelagic limestone sequence described by Bandel (1972) in the Carnic Alps. Bandel $(1972,1974)$ considered the "pelagic limestone with common redeposited beds" as transitional between the basin floor and the shallow-water platform. The major source of lithoclasts is interpreted as bottom reworking of sediment during downslope movement. 
a

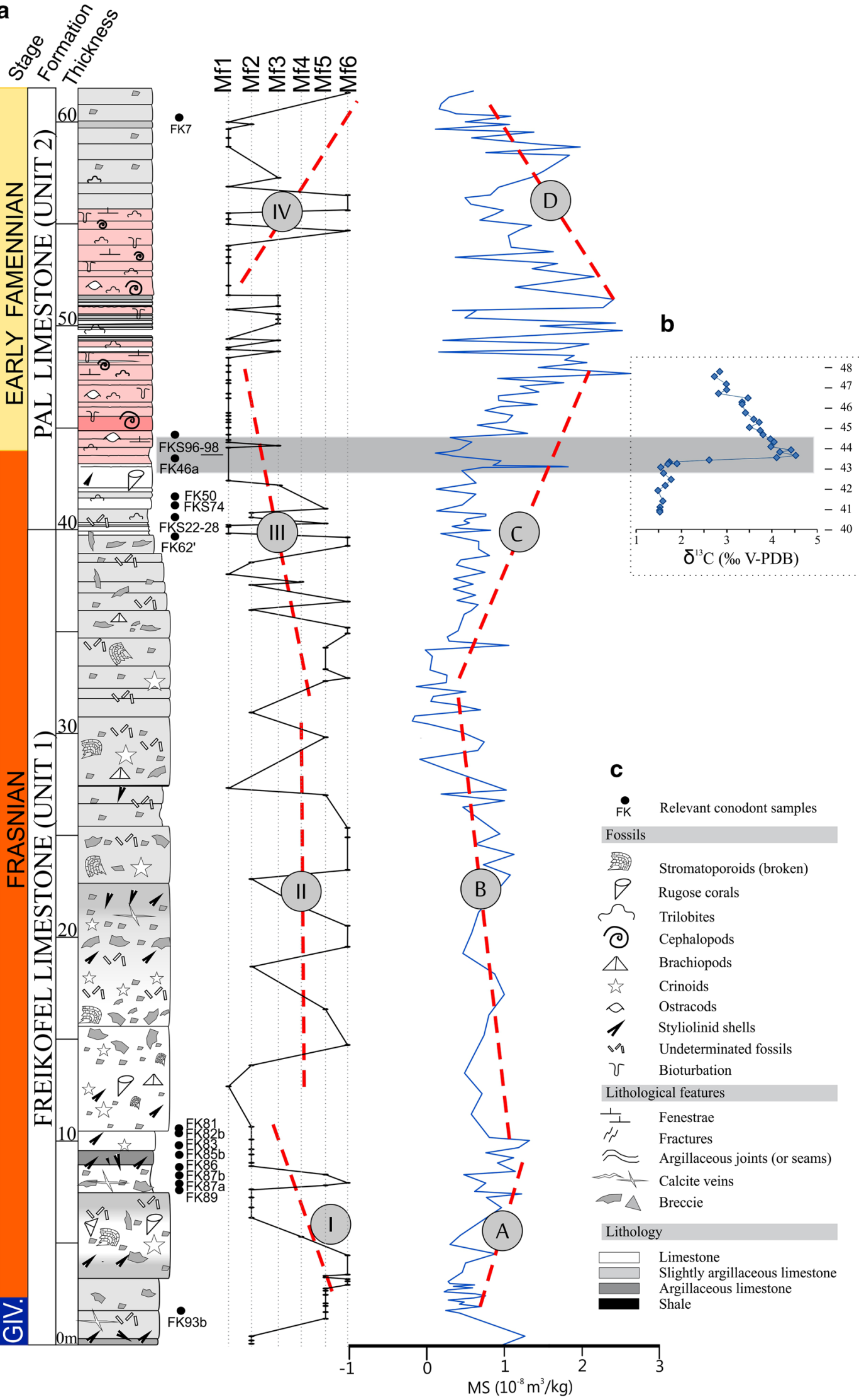


4 Fig. 6 a Schematic sedimentological log, lithostratigraphic units, microfacies trends, and magnetic susceptibility curves. Red dash line represents trends in microfacies (I-IV) and magnetic susceptibility ( $A$, $B, C$, and $D$ ) evolution. b Stable carbon isotope curve across the Frasnian-Famennian boundary. c Legend for symbols used in figures

\section{MF4: crinoidal bioclastic packstone (Fig. 8b)}

This microfacies is not frequent and mainly occurs in Unit 1 in association either with MF5 and MF2 through vertical grading or as lithoclasts in MF6. Except for crinoid debris, bioclasts are rare and often unidentifiable but the sorting is good. Crinoids are surrounded by syntaxial cement and have an average size around $0.35 \mathrm{~mm}$. The bioclasts are commonly associated with irregularly shaped peloids with an average size around $0.2 \mathrm{~mm}$. However, the peloids included in a packstone texture are sometimes difficult to be distinguished from the matrix.

\section{Interpretation:}

The general good sorting of the allochems suggests a depositional setting where the water agitation is, at least, temporarily high. Although, the packstone texture and its micritic matrix need relatively quiet conditions, likely under fair weather wave base (FWWB), to be deposited. The significant proportion of crinoids over other biogenic components suggests either a setting located in the vicinity of crinoidal meadows or a mechanical sorting of the allochems prior to deposition. The occurrence of this microfacies in association with MF5, interpreted as belonging to a turbiditic sequence (see below), and the vertical grading from MF5 through MF4 and also from MF4 through MF2 supports a mechanical sorting of the crinoids during turbulent flow such as turbidite. Sedimentological criteria observed in this microfacies are interpreted as part of the ideal turbiditic deposition occurring in Bouma sequence (e.g., Tb-c interval; Bouma 1962). Equivalent interval for "allodapic" limestone of Meischner (1964) corresponds to Zone 1c, 2a, and b.

\section{MF5: mud peloids crinoidal grainstone (Fig. 8c, $d, f, i)$}

This microfacies is observed within Unit 1, in association with microfacies MF6 either as filling the inter-lithoclastic voids in the rudstone texture (Fig. 8d) or as large lithoclasts (Fig. 8e). Less frequently, MF5 can be observed in association with MF4 either through a graded or sharp transition or as lenticular occurrences (Fig. 7g). Peloids (average size of $0.25 \mathrm{~mm}$ ) are abundant and locally very well-sorted (Fig. 8f). They commonly display different size and shape ("lithic" or "mud" peloids). According to Flügel (2004), mud peloids are variously shaped micritic grains caused by the reworking of lithified carbonate mud and micritic clasts. Locally, thin laminations underlined by the alternation of small- and larger-sized peloid levels occur. These laminations are often planar but cross-laminations are locally observed. Local fining upward grading from MF5 toward packstone and wackestone (MF4, MF2) are observed. Crinoids are usually disarticulated with an average size around $0.3 \mathrm{~mm}$ and usually show syntaxial cement. Calcispheres are frequent (Fig. 8g) while brachiopods, foraminifera (Frondilina tailferensis; Mamet et al. 1985, Fig. 8h), and unidentifiable bioclasts are poorly represented.

\section{Interpretation}

The grainstone texture, with a generally good sorting and the local thin- and cross-lamination as well as the absence of fine-grained particles, suggests a depositional setting where water agitation was significant. The common occurrence of calcispheres and crinoids supports a depositional setting influenced by shallow-water setting. Indeed, calcispheres and crinoids are, respectively, found in lagoon and back- to fore-reef setting within the FWWB. These allochems are thus interpreted as reworking of the shallower sediments during more energetic events such as storm waves, or downward transport along the fore-slope environment by gravity currents. The local fining upward grading toward wackestone-packstone (MF2, MF4) and the presence of wackestone-packstone intraclasts in the grainstone texture are arguments in favor of gravity-flow deposit such as turbidite. Indeed, storm deposits do not display grading. Considering the presence of wackestone-packstone intraclasts (MF2), which are interpreted as background sedimentation (see interpretation of MF2), the depositional setting of MF5 might be located under the FWWB. Similar microfacies have been described by May (1994) and Pas et al. (2013) for the fore-reef-slope environment from the Rhenisches Schiefergebirge (Germany) and are interpreted as a part of the general pattern visible in "allodapic" limestone (Zone 1b; Meischner 1964) and in the ideal turbiditic sequence of Bouma (division Tb; Bouma 1962). Other sedimentological criteria such as the presence of lamination, local fining upward sequences also support a deposition related to turbidity currents.

\section{MF6: lithoclastic rudstone (Figs. 8d, e and 9)}

This microfacies occurs mainly in Unit 1 and appears as several-dm to several-m-thick beds (Fig. 4b) intercalated within dm-thick beds of MF2 and MF4. At the outcrop scale, a fining upward grading occurs locally depending of the alteration. MF6 corresponds to a moderately sorted 

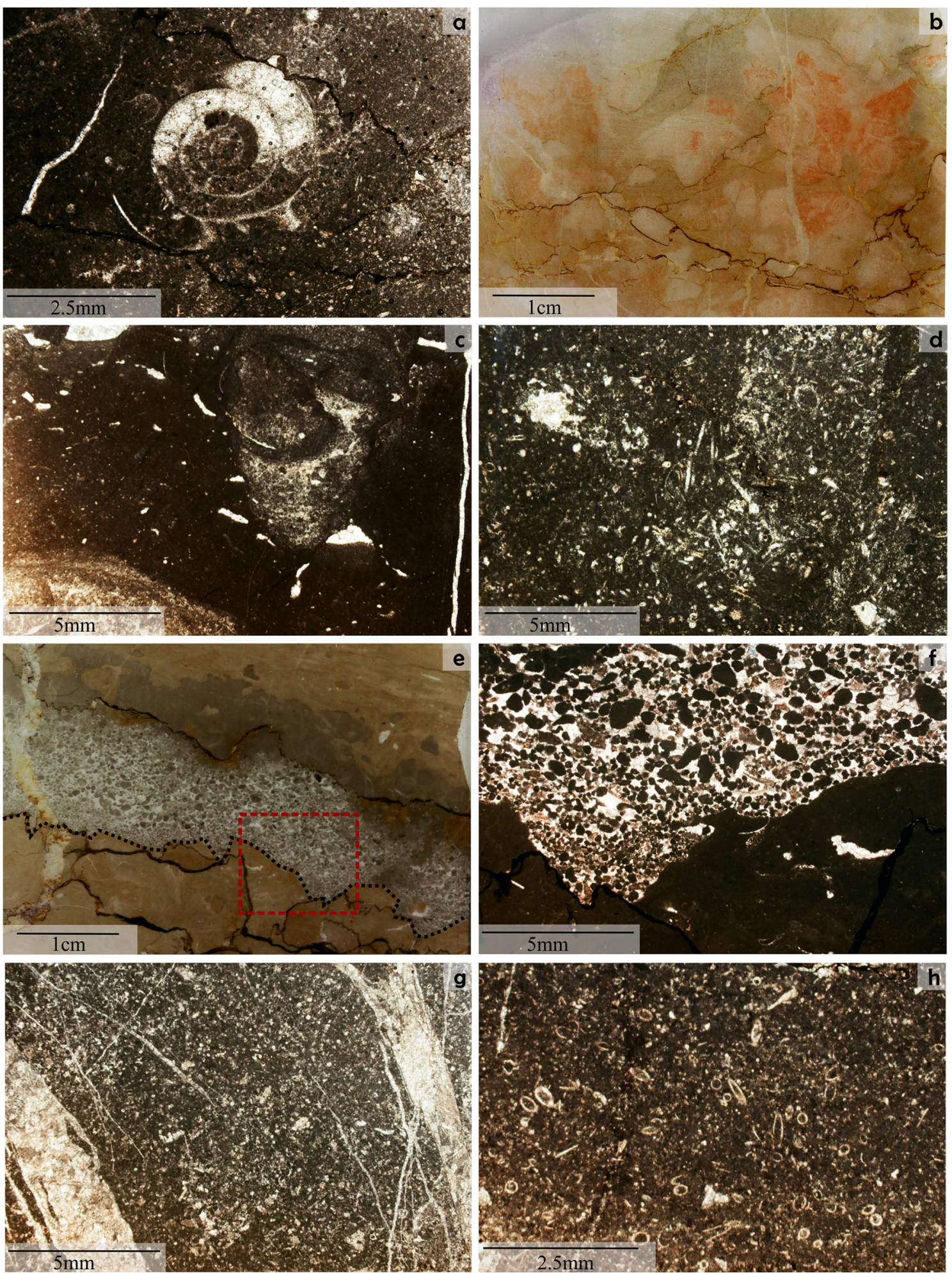

accumulation of various rounded to sub-angular-shaped several-mm to tens of $\mathrm{cm}$-sized lithoclasts corresponding to MF1, MF2, MF4, and MF5 (Figs. 8e, 9b). The dominant texture of this microfacies is rudstone even if a floatstone texture occurs (Fig. 9a). In the rudstone, the space between lithoclasts is usually filled with smaller grains with a grainstone texture cemented by sparite (Figs. 8d, 9c). These grains have an average size of $0.3 \mathrm{~mm}$ and are mainly represented by mud peloids (locally $70 \%$ of the filled space), calcispheres, brachiopod and ostracod shell 
4 Fig. 7 Microfacies from the distal fore-reef deposits of the Freikofel section. Photomicrographs of thin sections oriented perpendicular to the bedding. Numbers preceded by FK correspond to bed numbers. a MF1 distal reef-slope deposits: fine-grained mudstone with a goniatite shell (FK 47a, transmitted light). b MF1 distal reef-slope deposits: fine-grained bioturbated mudstone (FK 41, scanned thin section). c MF1 distal reef-slope deposits: fine-grained mudstone with fenestrae and bioturbation (FK44a, transmitted light). d MF1 distal reef-slope deposits: accumulation of sponge spicule in a bioturbated mudstone (FK01, transmitted light). e MF1 distal reef-slope deposits: intercalation of a lithoclastic grainstone layer (MF3) within a mudstone (FK30, scanned thin section). f MF1 distal reef-slope deposits: close-up on a lithoclastic grainstone layer intercalation occurring in MF1 mudstone (for location, see inset in e) (FK30, transmitted light). g MF2 intermediate to distal reef-slope deposits: fine-grained bioclastic wackestone-packstone with peloidal grainstone intercalation (FK97, transmitted light). h MF2 intermediate to distal reef-slope deposits: fine-grained rich styliolinid packstone (FK93, transmitted light)

fragments, and styliolinids. Locally, centimeter-sized stromatoporoid and rugose coral debris occur. Unidentifiable bioclasts are common. In the floatstone, the interlithoclastic voids are also filled with grainstone texture even if locally a packstone texture occurs.

\section{Interpretation}

This facies was first described as "Lithoklastkalk" by Bandel (1972) and later as "intraclast parabreccia" by Spalletta et al. (1983) and Spalletta and Vai (1984). These authors interpret these facies as the result of the concurrent action of relevant seismic shocks that induced tsunamis, back currents, and related turbidity current. The m-thick lithoclastic beds characterizing MF6 combined with local occurrence of fining upward sequences passing upward to wackestone and mudstone interbeds are diagnostic features of turbiditic sequence (Bouma 1962; Mutti 1977). However, the rare occurrence of a floatstone texture might reveal a deposition rather influenced by debris flow. The local intercalation of wackestone and mudstone (MF2) interbeds corresponding to autochthonous sedimentation confirms a depositional setting located below the SWB, in an off-reef pelagic/hemipelagic environment for MF6. The abundance of lithoclasts originated from intermediate slope and off-reef pelagic/hemipelagic environment (see MF2, MF3, and MF4) indicate a reworking of lithified materials from different sources located in a fore-reef-slope setting. The low ratio between reef-builder remains and lithoclasts indicates rather gravity flow originated from the fore-reef slope than the shallow-reef habitat. This microfacies corresponds to the Zone 1a in the ideal "allodapic" sequence of Meischner (1964) and division Ta in the ideal turbiditic sequence of Bouma (1962). To conclude, this microfacies is mostly in relation with turbiditic flow even when debris flow likely plays a role as well.

\section{Discussion}

\section{Depositional environments}

Petrographic analyses from the upper part of the Freikofel section led to the definition of six microfacies representing fore-reef slope to distal-reef floor depositional setting where gravity-flow processes play a significant role during the sedimentation (Fig. 10). In this simplified model, the more distal setting is characterized by deeper slope to distal reef floor autochthonous sedimentation (MF1, MF3), temporarily influenced by distal turbiditic current (MF3). These distal turbidites are comparable to turbiditic fringe lobe developed in basin floor environment (e.g., Mutti 1977). In the intermediate to distal fore-reef-slope area, an interplay of various gravity processes (debris and turbiditic flow) dominates the depositional style and corresponds to an accumulation of various autochthonous and allochthonous sediments (MF6, MF5, MF4, and MF2); these sediments represent different portions of deposition occurring in Bouma (e.g., Ta, Tb, Tc, Td-e; Bouma 1962) or Meischner sequence; it is equivalent for carbonate environment (e.g., Zones 1, 2, and 3; Meischner 1964). Therefore, these microfacies could reflect a deposition in a channel lobe system in an outer fan turbiditic model (e.g., Mutti 1977).

The temporal evolution of microfacies throughout the studied section (Fig. 6) demonstrates two major palaeoenvironmental trends corresponding to Unit 1 (Freikofel Limestone) and Unit 2 (Pal Limestone), respectively. During the sedimentation of Unit 1, the microfacies curve (Fig. 6) shows mainly an aggrading trend with numerous oscillations between MF6, MF5, MF4, and MF2, which are interpreted as transitions between parts of the Bouma sequence recognized in turbiditic deposits. The occurrence of a mixed Late Eifelian-Early Givetian and Early Frasnian conodont fauna in the lower part of Unit 1 proves that the thick breccia levels are likely connected to the Late Givetian major rift pulse recognized in the Carnic Alps (Ebner et al. 1980; Spalletta et al. 1980; Vai 1980). This rift phase would have deeply altered the morphology of the fore-reef setting from a gentle slope to a steep fault scarps, resulting in a severe reworking of slope and/or platform margin settings. According to various authors (Vai 1976; Kreutzer 1992a, b; Schönlaub and Histon 2000), the maximum development of the Devonian carbonate platform in the Carnic Alps seems to have occurred in the Givetian and Early Middle Frasnian periods (Kreutzer 1992a; Vai 1998), which is consistent with the worldwide blossoming of Devonian carbonate platform (Copper 2002). Therefore, this period is interpreted here as the interval where the production of reef-derived debris susceptible to move downward reached its maximum. For instance, in the fore-reef setting of the Brilon Reef 

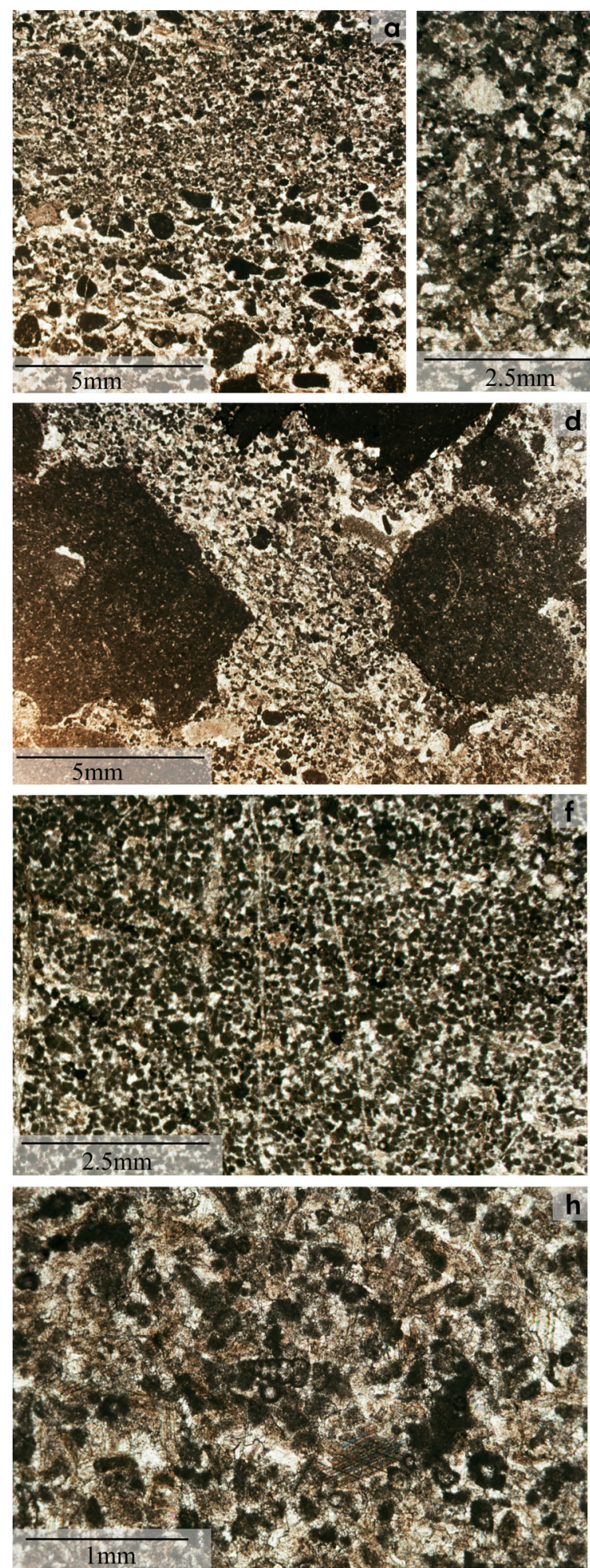

Complex (eastern Rheinisches Schiefergebirge), the highest proportion in reef-related debris extends from the Late Givetian to the Early Frasnian period (Pas et al. 2013), which is consistent with the maximal extension of the platform. This relationship between maximal extension of platform and highest proportion of reef-related debris was
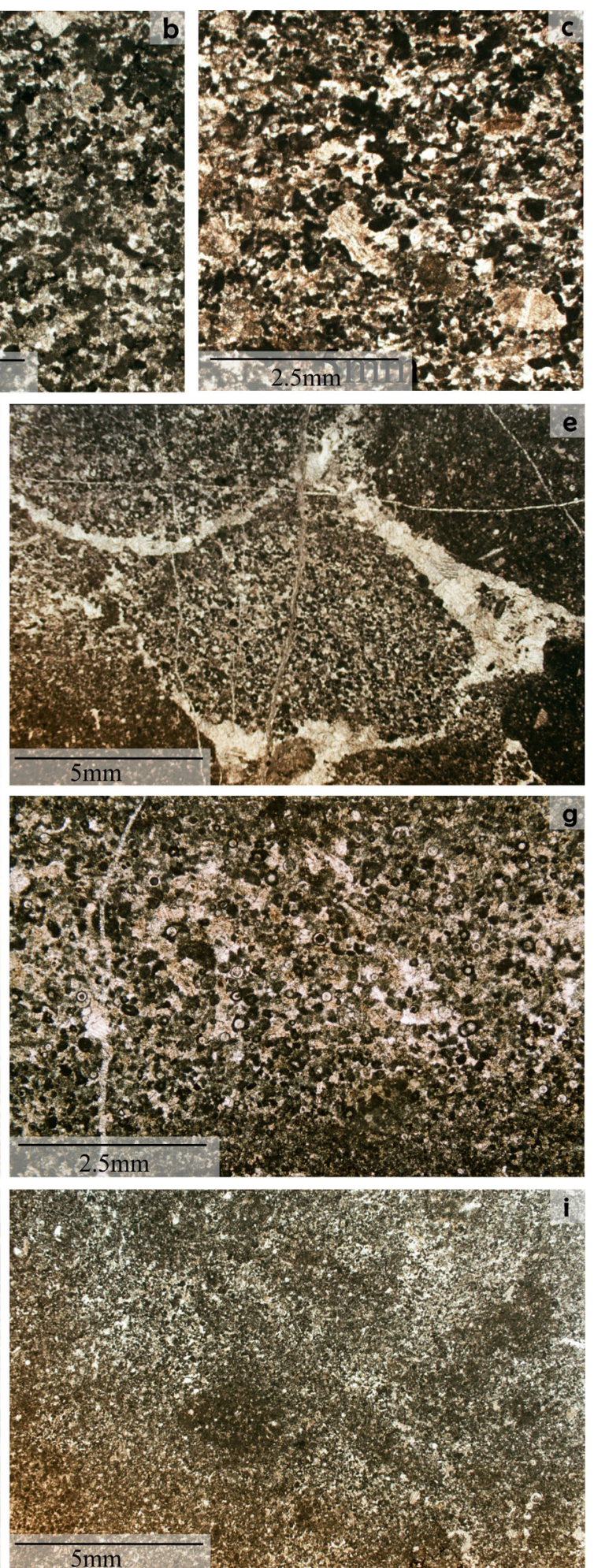

also recognized in the reef complex of the Australian Canning Basin (Playford et al. 1980). However, in the Freikofel section, the Lower Frasnian succession records low occurrence of reef-builder debris and/or shallowwater-derived allochems compared to the high proportion of fore-reef-slope-derived lithoclasts (e.g., MF2, MF4, and 
4 Fig. 8 Microfacies from the intermediate to distal reef slope of the Freikofel section. Photomicrographs of thin section oriented perpendicular to the bedding. a MF3 distal reef-slope deposits: fining upward sequence in a lithoclastic grainstone (FK11, transmitted light). b MF4 intermediate reef-slope deposits: crinodal packstone (FK64, transmitted light). c Intermediate to distal reef-slope deposits: crinoidal grainstone (FK87, transmitted light). d MF6 intermediate to distal reef-slope deposits: lithoclastic rudstone with an inter-lithoclastic void filled with a peloidal grainstone (FK13a, transmitted light). e MF6 intermediate reef-slope deposits: lithoclastic grainstone showing three types of lithoclasts (pgl; cpl; wpl) (FK79a", transmitted light). f Wellsorted peloidal grainstone (FK93c, transmitted light). g MF5 intermediate reef-slope deposits: calcispheres-rich peloidal grainstone (FK75c", transmitted light) h MF5: intermediate reef-slope deposits: fine-grained micritic clasts grainstone showing foraminifera Frondilina tailferensis; Mamet et al. (1985) (FK87b, transmitted light). i MF5 intermediate reef-slope deposits: rich fine-grained peloidal grainstone corresponding to a pelsparite (FK79a, transmitted light)

MF5). This situation rather suggests a deposition during a period of low carbonate productivity within the shallowwater setting. This hypothesis is supported by the data from Schnellbächer (2010) who reported that the highest proportion of reef-builder debris in the Freikofel section (Cellon Limestone; see Fig. 4) occurs during the EmsianEifelian interval. There is thus a contradiction between the literature and our new data. Indeed, the low occurrence of shallow-water remains within the Unit 1 might signify that the early Frasnian reefs of the Carnic Alps were in decline earlier than in most of the reef localities throughout the Middle-Upper Devonian world. This might be related to the active extensional tectonic regime (Ebner et al. 1980; Spalletta et al. 1980; Vai 1980; Spalletta and Vai 1984), which increased the subsidence rate leading progressive drowning of reef and in the Carnic Alps locality to important reworking of the platform.

Throughout the upper part of Unit 1, the thickness of beds and proportion in MF6 and MF5 decreases in favor of MF4 and MF2. The transition from Unit 1 to Unit 2 is marked by a strong deepening, which is characterized by the transition from an intermediate fore-reef slope intensely influenced by gravity-flow deposits to a hemipelagic/pelagic environment in the distal slope to off-reef areas, less influenced by gravity-flow processes. The microfacies curve corresponding to the Pal Limestone records mainly an aggrading trend in distal reef-slope to off-reef settings (MF1, MF2), characterized by pink to red thin-bedded limestone extending from the upper Frasnian into the lower Famennian. The occurrence of thin-turbiditic interbeds reflects a depositional setting still influenced by fore-reef slope reworking

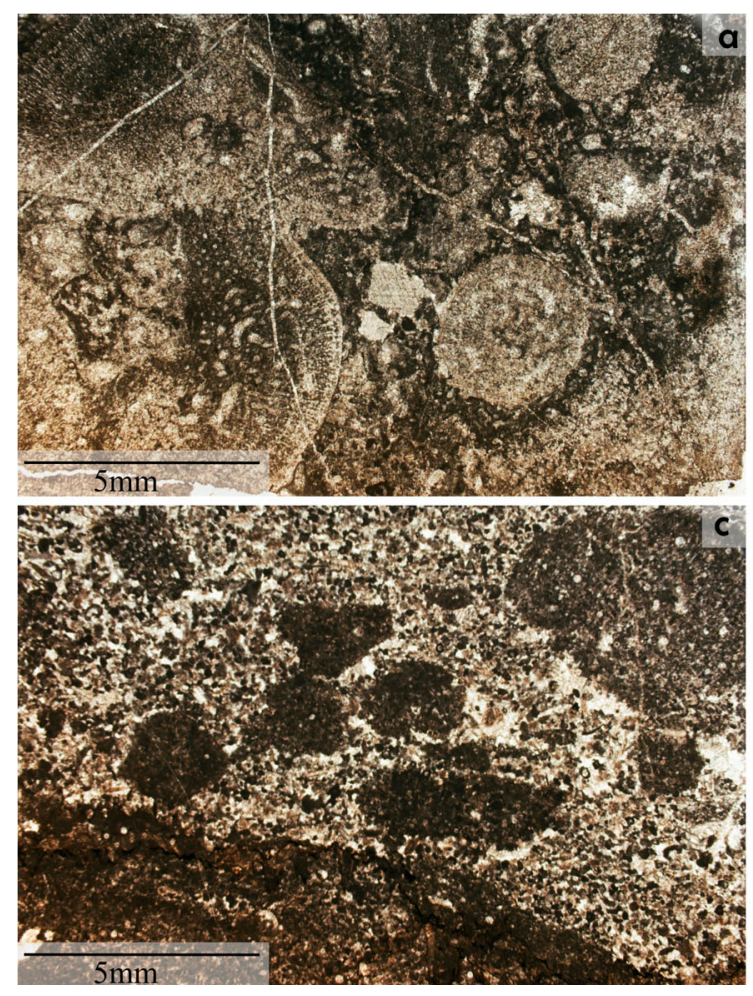

Fig. 9 Microfacies from the intermediate to distal reef-slope of the Freikofel section. Photomicrographs of thin section oriented perpendicular to the bedding. a MF6: flaotstone with stromatoporoids encrusted with Renalcis (FK 74c, transmitted light). b MF6 intermediate reef-slope deposits: lithoclastic rudstone showing several types

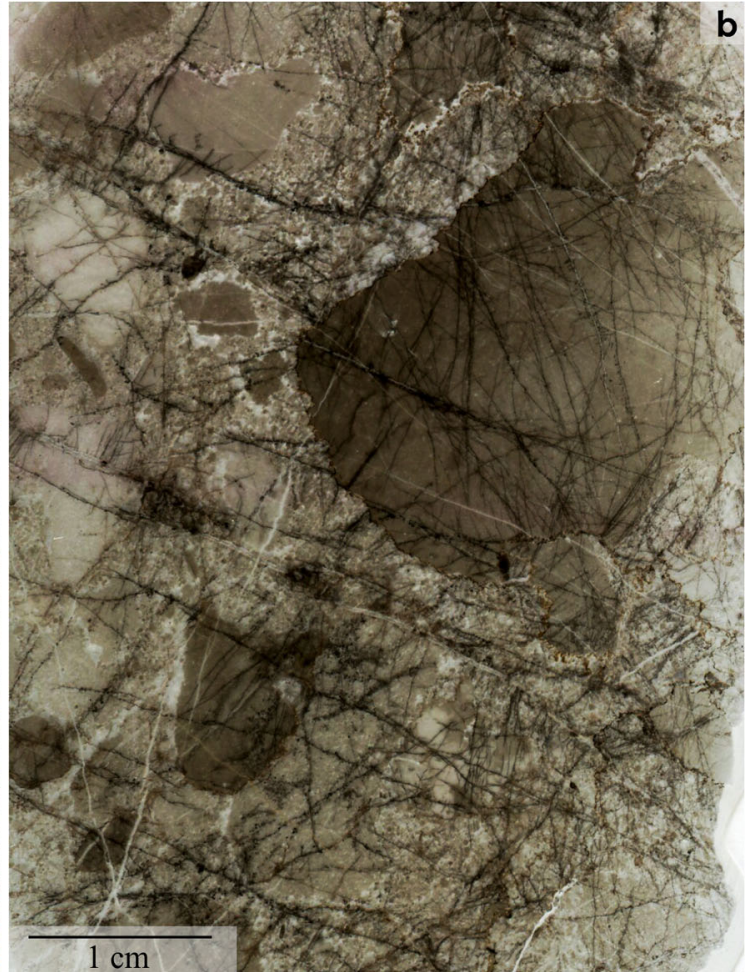

of lithoclasts, which can be differentiated on the basis of color (FK93i, scanned thin section). c Transition between MF2 bioclastic wackestone-packstone and MF6 lithoclastic rudstone (lithoclasts are reworking of MF2) (FK66b, transmitted light) 
Fig. 10 Sedimentary model of the Freikofel section showing the distal slope sedimentary domain described herein. Numbers correspond to microfacies (see text for more information)

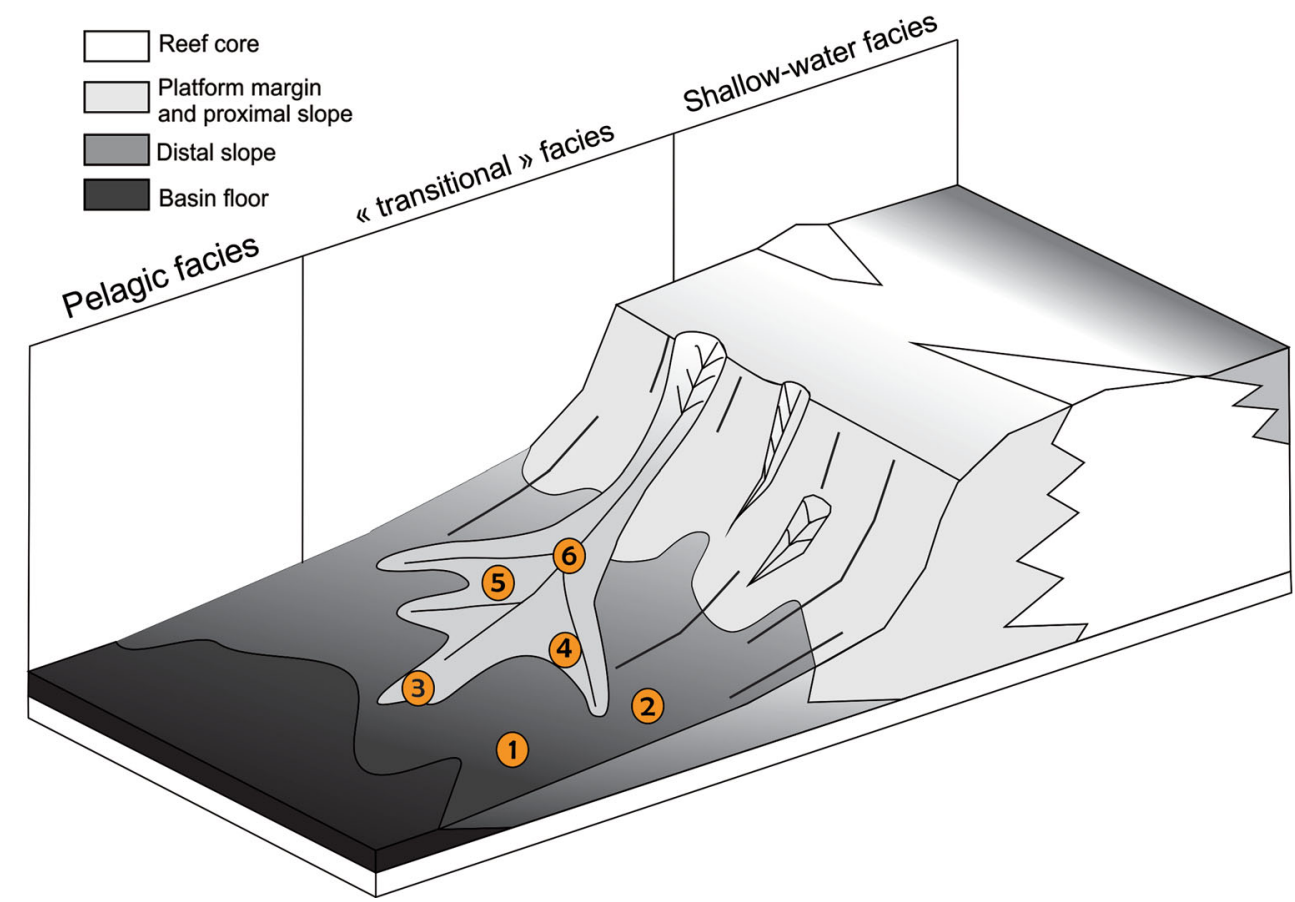

transported downslope by gravity currents. The predominance of the MF1 within the Unit 2 indicates both an increase in water depth and a strong decrease within the reef- and fore-reef-slope-related influxes toward the basin. This decrease in reef- and fore-reef might be related to the Late Frasnian sea-level rise (Johnson et al. 1985). In comparison with the thick breccia level of Unit 1, the thinturbiditic layers of Unit 2 suggest a change from a steep erosional slope to either a backstepping margin or a just more depositional rather than erosional margin. The margin backstepping is easily supported by the long-term Frasnian eustatic sea-level rise recognized worldwide, causing the demise and drowning of the shallow-water carbonate platform in a global scale (Eder and Franke 1982; Johnson et al. 1985). Furthermore, in the Carnic Alps area, eustatic sealevel rise is likely enhanced by the tectonically active subsidence starting during the Late Givetian major extensional pulse (Ebner et al. 1980; Spalletta et al. 1980; Vai 1980). These global and local changes appear to be connected to the Kellwasser event interval at the end of the Frasnian, which is considered to be one of the major extinction events of the Phanerozoic (Sepkoski 1995; McGhee et al. 2013) and marks the end of the Devonian reef communities. The two positive $\delta^{13} \mathrm{C}$ excursions commonly observed for the Kellwasser event interval were recognized in the Carnic Alps (Wolayer Glacier section) by Joachimski et al. (1994). Although black shale levels do not occur in the Freikofel section, a distinctive positive shift of about 3 promille in the $\delta^{13} \mathrm{C}$ trend within the upper part of the linguiformis conodont Zone confirms the evidence of the Upper Kellwasser event. The significance of the Late Frasnian sea-level rise is also highlighted by the widespread deposition of red nodular limestone overlying the thick sequence of reef and fore-reef "transitional" facies of the Devonian Carnic Alps carbonate platform (Schönlaub and Histon 2000; Vai 1998).

Magnetic susceptibility and trace and major element geochemistry

The MS and geochemical curves prepared for the section studied are shown in Figs. 11 and 12. The MS values for the Middle and Upper Devonian Freikofel Limestone (Unit 1) and Pal Limestone (Unit 2) are very low, ranging from -0.18 to $2.7 \times 10^{-8} \mathrm{~m}^{3} / \mathrm{kg}$ with an average value of $7.73 \times 7 \times$ $10^{-9} \mathrm{~m}^{3} / \mathrm{kg}$. These MS values are much lower than the $\mathrm{MS}_{\text {marine standard }}$ of $5.5 \times 10^{-8} \mathrm{~m}^{3} / \mathrm{kg}$ defined by Ellwood et al. (2011) on the basis of $\sim 11,000$ marine rock samples. They are also lower than average MS values of timeequivalent fore-reef setting from the Rhenohercynian basin in Belgium (3.3 $\times 10^{-8} \mathrm{~m}^{3} / \mathrm{kg}$; Da Silva et al. 2009). The stratigraphic distribution of some selected elements commonly used as reliable tracers of the lithogenic input $(\mathrm{Zr}, \mathrm{Al}$, K, Si, and Ti) (Sliwinsky and Whalen 2010) was plotted against the MS curve (Fig. 11). The distribution of these elements follows the same large-scaled trend than MS. This relatively parallel evolution points to a MS signals linked to the amount of terrestrial input. Furthermore, there is a strong positive correlation $(r=0.95)$ between $\mathrm{Al}$ and Ti. According to Pratt et al. (1986), since Ti is not incorporated in the clay minerals fraction formed during diagenesis (e.g., illite), a good correlation between $\mathrm{Ti}$ and $\mathrm{Al}$ points to primary clay mineral assemblages was not transformed by diagenesis. MS 
MS and clastic input proxies

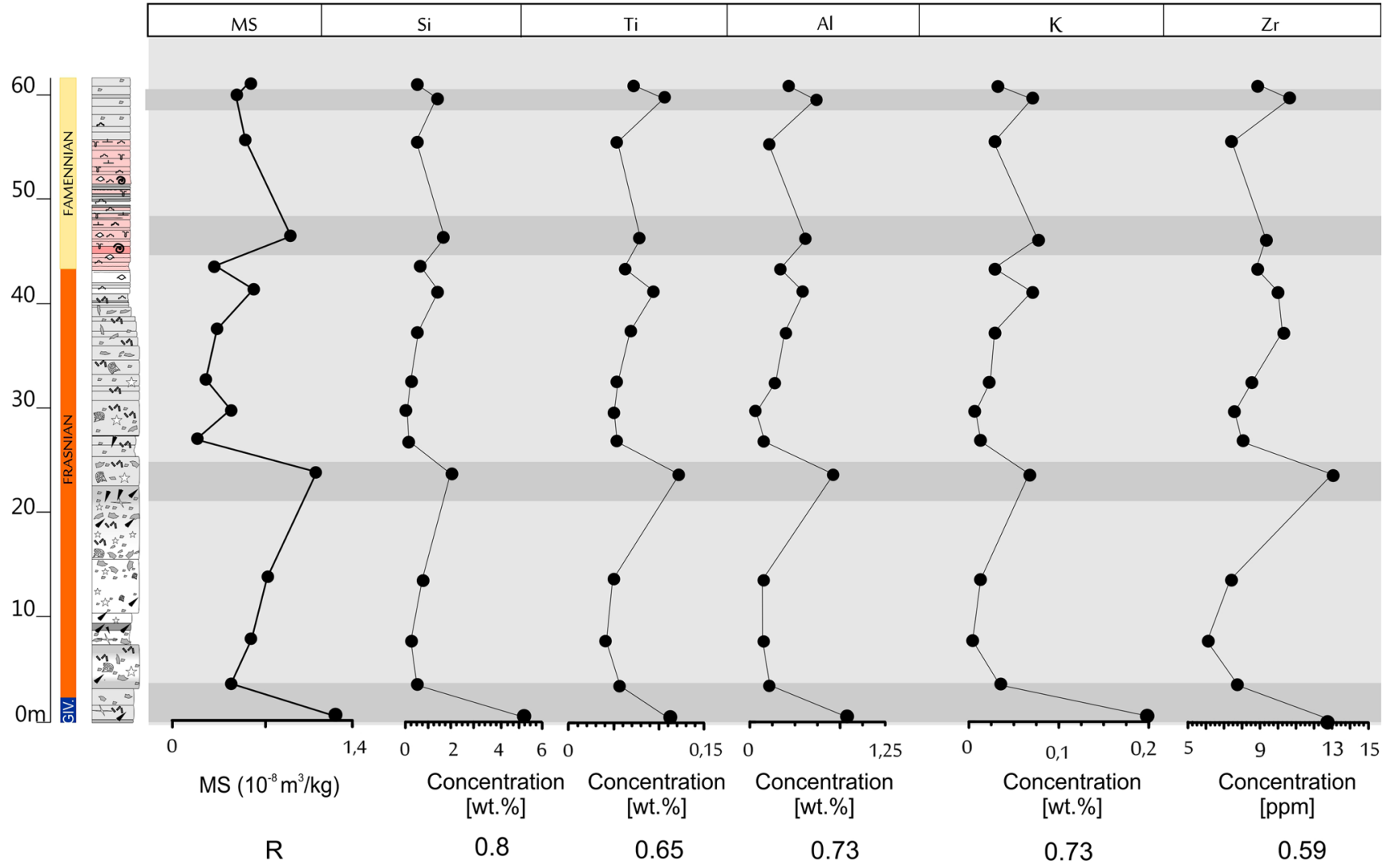

Fig. 11 Chemostratigraphic profiles of elements used as proxies for terrigenous clastic influxes into marine depositional basins. Plotted also is the corresponding magnetic susceptibility (MS) profile. Shaded areas are meant to help visualize common trends

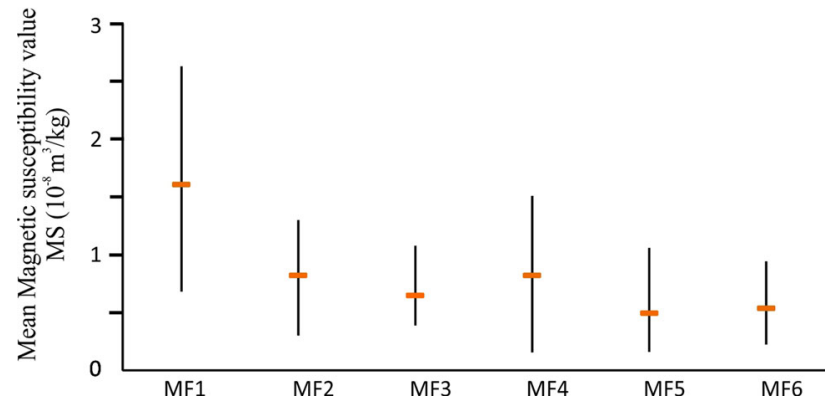

Fig. 12 Mean MS values on relative proximity transect illustrated by the position of microfacies from proximal to distal location

values attest thus of an average very low terrestrial influx seaward during the deposition of the Freikofel and Pal Limestones. The location of the "Proto Alps" basin around $30^{\circ} \mathrm{S}$ (Schönlaub 1992; see Fig. 1) during Middle and Late Devonian times was likely far from a continental or volcanic source area, which enabled the formation of an almost pure carbonate system. In the Rhenohercynian basin in Belgium, the vicinity with the Old Red Continent in the north might have triggered the higher values of MS recorded in the Givetian and Frasnian times.
At a large scale, the MS curve performed for the Freikofel section can be divided in four successive trends, respectively, called A, B, C, and D in Fig. 6. Trends A and B correspond to Unit 1 while trends $C$ and $D$ depict the evolution of Unit 2 . Comparison between long-term trends in microfacies (MF I, II, III, and IV) and MS profiles mainly are in opposition. In order to get a better understanding of the parameters influencing long-scaled trends and the opposition between MS and microfacies (MF) profiles, we coupled MS, MF, and geochemical analyses. Average MS values for each microfacies (Fig. 12) display a general increase from proximal to distal setting excepted the slight decrease from MF4 to MF3 and MF5 to MF6. In the Freikofel area, the distality appears to be one of the most significant parameters influencing MS variations, but water turbulence and reworking also seem to play an important role. Usually, data related to carbonate platform (Da Silva and Boulvain 2006) support the notion that proximal microfacies possess a higher value of MS than distal ones because of vicinity with a terrestrial source. In our case, the average MS value shows just the opposite trends (increase in the average MS value with the distality). This situation has already been remarked for Belgian Eifelian fore-reef environment (Mabille and Boulvain 2007) as well as for Belgian 
and Canadian Frasnian mound and atoll (Da Silva et al. 2009), and this can be reasonably explained considering the location of the depositional setting compared to the continent. Indeed, if the sedimentary environment is far enough from terrestrial supplies, which is assumed for the Freikofel section, we can consider that the detrital inputs are homogenized and have the same influence on each microfacies. In such case, the carbonate productivity/sedimentary rate will play a more significant role in the MS variations. Low sedimentary rate (e.g., MF1, MF2, and MF4) will lead to condensed levels and thus to a concentration of magnetic minerals while higher sedimentary rate will decrease the concentration in MS carrying minerals by dilution. Water agitation is suggested mainly for MF6, MF5, and MF3, which are influenced by high turbulence of water preventing the settlement of MS carrying minerals. The higher mean MS value for MF6 compared to MF5 is thought to be related to the abundant occurrence of lithoclasts from MF2 and MF4 integrated within the MF6. In conclusion, MS variations in Freikofel can be explained using palaeoenvironmental parameters such as carbonate productivity/sedimentary rate and water agitation.

\section{Conclusions}

1. The Freikofel section provides an outstanding continuous succession of about $10 \mathrm{Ma}$ in a fore-reef setting and delivers an important contribution to the understanding of the Carnic Alps platform/basin evolution during the Mid-Late Devonian. The stratigraphic framework of the entire section is well documented by conodont biostratigraphy.

2. Based on the detailed microfacies and field observations, the development of the Latest Givetian to Early Famennian fore-reef to distal slope facies of the Freikofel section can be reconstructed. Two major evolutionary phases are recognized such as (a) dismantlement of the Eifelian-Frasnian platform starting during the Early Frasnian with one of the causes being the Late Givetian major rift pulse recognized in the area. The dismantlement lasted till Late Frasnian; (b) stepwise withdrawal of the shallow-water influxes during the Late Frasnian and significant deepening of the Carnic Alps area during the Latest Frasnian and Early Famennian as a result of the Kellwasser event.

3. Though the Upper Kellwasser event layer does not show the specific lithological characteristics (e.g., shales), $\delta^{13} \mathrm{C}$ values show a major positive excursion.

4. The detailed sedimentological study of the Freikofel section demonstrates the use of the "transitional" facies as reliable tool for temporal consideration where the occurrence of datable fossils is limited in shallowwater area.
5. The Freikofel and Pal Limestones show MS values (from -0.18 to $2.710^{-8} \mathrm{~m}^{3} / \mathrm{kg}$ ) much lower than (1)

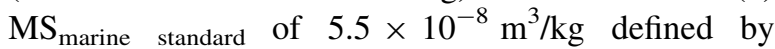
Ellwood et al. (2011) on the basis of $\sim 11,000$ marine rock samples and (2) time-equivalent fore-reef setting from the Rhenohercynian basin in Belgium $\left(3.3 \times 10^{-8} \mathrm{~m}^{3} / \mathrm{kg}\right.$; Da Silva et al. 2009).

6. Parallelism between MS and proxy suites for terrestrial input suggests an inherent interdependence and changes in detrital input as the main driver of the oceanographic changes, which produced the observed geochemical variations. MS coupled with MF analyses demonstrates distality as the main palaeoenvironmental parameter leading to variation in the MS signal. In addition, two other MS controlling processes are also underlined such as (1) water agitation likely hampers MS carrying minerals to settle and (2) carbonate productivity that lowers the MS intensity by diluting the MS responsible minerals.

Acknowledgments This paper is a contribution to the UNESCO International Geoscience Program (IGCP) number 580; entitled "Application of magnetic susceptibility as a palaeoclimatic proxy on Paleozoic sedimentary rocks and characterization of the magnetic signal" and number 596 (Climate change and biodiversity patterns in the Mid-Paleozoic). This study was financially supported by the Grants IGCP 580 and NAP0017 (DP, ACDS), the FWF P 23775-B17 (TS and EK). This work was supported by a PhD fellowship awarded by the Research Foundation-Flanders (FWO) assigned to DDV. Philip Schnellbächer (Geognos Bertle, Austria) is thanked for providing his master thesis. The magmatic petrology laboratory of Liège University (N. Delmelle and J. Vander Auwera) is thanked for access and help on the geochemical measurement. For discussion on conodont biostratigraphy of the Freikofel area, we thank Maria Cristina Perri and Claudia Spalletta (University of Bologna, Italy). Finally, we gratefully acknowledge the two reviewers (Hans Peter Schönlaub and Claudia Spalletta) for their helpful and pertinent remarks that significantly improved the quality of this manuscript.

\section{References}

Bandel K (1969) Feinstratigraphische und biofazielle Untersuchungen unterdevonischer Kalke am Fuß der seewarte (Wolayer see: zentrale Karnische Alpen). Jb Geol B A 112:197-234

Bandel K (1972) Palökologie und Paläogeographie im Devon und Unterkarbon der zentralen Karnischen Alpen. Palaeontographica A 141(1-4):1-117

Bandel K (1974) Deep-water limestones from the Devonian-carboniferous of the Carnic Alps, Austria. Spec Publ Int Assoc Sediment 1:93-115

Bouma A (1962) Sedimentology of some flysch deposits. Elsevier, New York, p 168

Brime C, Perri MC, Pondrelli M, Spalletta C, Venturini C (2008) Polyphase metamorphism in the eastern Carnic Alps (N Italy-S Austria): clay minerals and conodont colour alteration index evidence. Int J Earth Sci 97:1213-1229

Copper P (2002) Silurian and Devonian reefs: 800 million years of global greenhouse between two ice ages. In: Kiessling W, Flügel 
E, Golonka J (eds) Phanerozoic reef patterns. SEPM special publication, vol 72, pp 181-238

Corradini C, Corriga MG (2010) Silurian and lowermost Devonian conodonts from the Passo Volaia area (Carnic Alps, Italy). Boll Soc Paleontol Italy 49(3):237-253

Corradini C, Corriga MG (2012) A Pridoli-Lochkovian conodont zonation in Sardinia and the Carnic Alps: implications for a global zonation scheme. Bull Geos 87(4):635-650. doi:10.3140/ bull.geosci.1304

Corradini C, Pondrelli M, Corriga MG, Simonetto L, Kido E, Suttner TJ, Spalletta C, Carta N (2012) Geology and stratigraphy of the Cason di Lanza area (Mount Zermula, Carnic Alps, Italy). Berichte des Institutes für Erdwissenschaften, Karl-FranzensUniversität Graz 17:83-103

Corriga MG, Corradini C (2009) Upper silurian and lower Devonian conodonts from the Monte Cocco II section (Carnic Alps, Italy). Bull Geosci 84(1):155-168. doi:10.3140bull.geosci.1112

Da Silva AC, Boulvain F (2006) Upper Devonian carbonate platform correlations and sea level variations recorded in magnetic susceptibility. Palaeogeog Palaeoclimatol Palaeoecol 240:373388

Da Silva AC, Mabille C, Boulvain F (2009) Influence of sedimentary setting on the use of magnetic susceptibility: examples from the Devonian of Belgium. Sedimentology 56(5):1292-1306

Dickson J (1965) A modified staining technique for carbonates in thin section. Nature 205:587

Dunham RJ (1962) Classification of carbonate rocks according to depositional texture. Mem Am Assoc Petrol Geol 1:108-121

Ebner F, Fenninger A, Holzer HL (1980) Die Rannach-Fazies des Grazer Paläozoikums. Mitt Abt Geol Paläontol Bergb Landesmus Joanneum 41:249-269

Eder W, Franke W (1982) Death of Devonian reefs. N Jb Geol Palaönt Abh 163:241-243

Ellwood BB, Tomkin JH, El Hassani A, Bultynck P, Brett CE, Schindler E, Feist R, Bartholomew AJ (2011) A climate-driven model and development of a floating point time scale for the entire middle Devonian givetian stage: a test using magnetostratigraphy susceptibility as a climate proxy. Palaeogeog Palaeoclimatol Palaeoecol 304(1-2):85-95

Embry AF, Klovan JE (1972) Absolute water depth limits of Late Devonian paleoecological zones. Geol Rundsch 61(2):672-686

Flügel E (2004) Microfacies analysis of carbonate rocks. Analysis, interpretation and application. Springer, Berlin

Galli G (1985) Depositional environments in the devonian limestone succession of the Cima Ombladet (Camic Alps, Italy). Facies 12(1):97-111

Hubmann B, Suttner T (2007) Siluro-Devonian Alpine reefs and pavements. Geol Soc Lond Spec Pub 275(1):95-107

Hubmann B, Ebner F, Ferretti A, Histon K, Kido E, Krainer K, Neubauer F, Schönlaub HP, Suttner TJ (2013) The Paleozoic Era (them). In: Piller WE (ed) The lithostratigraphic units of the Austrian stratigraphic chart 2004 (sedimentary successions). Abh Geol B A 66(1):9-133

Hüneke H (2006) Erosion and deposition from bottom currents during the Givetian and Frasnian: response to intensified oceanic circulation between Gondwana and Laurussia. Palaeogeog Palaeoclimatol Palaeoecol 234:146-167

Hüneke H (2007) Pelagic carbonate ooze reworked by bottom currents during Devonian approach of the continents Gondwana and Laurussia. Geol Soc Lond Spec Pub 276:299-328

Joachimski MM, Buggisch W, Anders T (1994) Mikrofazies, Conodontenstratigraphie und Isotopengeochemie des FrasneFamenne-Grenzprofils Wolayer Gletscher (Karnische Alpen). Abh Geol B A 50:183-195

Johnson JG, Klapper G, Sandberg CA (1985) Devonian eustatic fluctuations in Euramerica. Geol Soc Am Bull 96:567-587
Königshof P, Savage NM, Lutat P, Sardsud A, Dopieralska J, Belka Z, Racki G (2012) Late Devonian sedimentary record of the Paleotethys Ocean-The Mae Sariang section, northwestern Thailand. J Asian Earth Sci 52:146-157

Kreutzer LH (1989) Reef-basin distance in the Devonian of the Carnic Alps. Ann Soc Geol Belg 112:159-163

Kreutzer LH (1990) Mikrofazies, stratigraphie und Paläogeographie des Zentralkarnischen Hauptkammes zwischen Seewarte und Cellon. Jb Geol B A 133(2):275-343

Kreutzer LH (1992a) Photo-Atlas of the variscan carbonate sequences in the Carnic Alps (Austria/Italy). Abh Geol B A 47:1-129

Kreutzer LH (1992b) Palinspastische Entzerrung und Neugliederung des Devons in den Zentralkarnischen Alpen aufgrund von neuen Untersuchungen. Jahrb Geol Bundesanstalt 135(1):261-272

Läufer AL, Hubich DH, Loeschke JL (2001) Variscan geodynamic evolution of the Carnic Alps (Austria/Italy). Int J Earth Sci 90(4):855-870

Lischka M (2007) Hangschuttsedimente einer devonischen Karbonatplattform-Mikrofazies und Provenienz des Detritus (Freikofel, Karnische Alpen). Universität Greifswald. Greifswald [unpublished BSc thesis], pp 1-54

Mabille C, Boulvain F (2007) Sedimentology and magnetic susceptibility of the Couvin Formation (Eifelian, South Western Belgium): carbonate platform initiation in a hostile world. Geol Belg 10(1-2):47-67

Mamet B, Naisse F, Perez S, Préat A (1985) Frondilina tailferensis, n. sp. Un foraminifère nouveau du Frasnien de la Belgique. Bull Soc Belg Geol 94(4):269-271

May A (1994) Microfacies controls on weathering of carbonate building stones: Devonian (northern Sauerland, Germany). Facies 30(1):193-208

McGhee GR, Clapham ME, Sheehan PM, Bottjer DJ, Droser ML (2013) A new ecological-severity ranking of major phanerozoic biodiversity crises. Palaeogeog Palaeoclimatol Palaeoecol 370:260-270

Meischner KD (1964) Allodapische Kalke. Turbidite in riff-nahen Sedimentations-Becken. Developm Sediment 3:156-191

Mutti E (1977) Distinctive thin-bedded turbidite facies and related depositional environments in the Eocene Hecho Group (Southcentral Pyrenees, Spain). Sedimentology 24(1):107-131

Oeckentorp-Küster P, Oeckentorp C (1992) Rugose Korallenfaunen des Mittel und Ober-Devons der zentralen Karnischen Alpen. Jb Geol B A 135(1):233-260

Pas D, Da Silva AC, Cornet P, Bultynck P, Königshof P, Boulvain F (2013) Sedimentary development of a continuous middle Devonian to mississippian section from the fore-reef fringe of the Brilon reef complex (Rheinisches Schiefergebirge, Germany). Facies 59(4):969-990. doi:10.1007/s10347-012-0351-z

Perri MC, Spalletta C (1998) Updating of the conodont biostratigraphy in the Carnic Alps (Italy). In: Perri M, Spalletta C (eds) Southern Alps field trip guidebook. ECOS VII. Giorn Geol 60 (spec issue), pp 116-119

Pettijohn FJ, Potter PE, Siever R (1972) Sand and sandstone. Springer, Berlin

Piller WE, Egger H, Erhart CW, Gross M, Harzhauser M, Hubmann B, van Husen D, Krenmayr H-G, Krystyn L, Lein R, Lukeneder A, Mandl GW, Rögl F, Roetzel R, Rupp C, Schnabel W, Schönlaub HP, Summesberger H, Wagreich M, Wesseley G (2004) Die stratigraphische Tabelle von Östereich 2004 (sedimentäre Folgen). Kommission für die paläontologische und stratigraphische Erforschung Österreichs, Österreichische Akademie der Wissenschaften und Österreichische Stratigraphische Kommission, Wien

Piper DJW (1978) Turbidite muds and silts on deepsea fans and abyssal plains. In: Stanley DJ, Kelling G (eds) Sedimentation and submarine canyons, fans, and trenches. Dowden, Hutchinson and Ross, Stroudsburg, pp 163-176 
Playford PE (1980) Devonian “Great Barrier Reef” of Canning Basin, Western Australia. Am Assoc Petrol Geol Bull 64:814-840

Pohler S (1982) Die Entwicklung der Flachwasserkarbonate im Mittel- und Oberdevon der Zentralen Karnischen Alpen (Seewartesockel zum S-Abfall der Hohen Warte). Rhenish Friedrich-Wilhelm University Bonn [unpublished diploma thesis], p 134

Pölsler P (1969a) Stratigraphie und Tektonik im Nordabfall des Findenigkofels (Silur bis Karbon; Karnische Alpen, Österreich). Jb Geol B A 112:355-398

Pölsler P (1969b) Conodonten aus dem Devon der Karnischen Alpen (Findenigkofel, Österreich). Jb Geol B A 112(2):399-440

Pratt LM, Claypool GE, King JD (1986) Geochemical imprint of depositional conditions on organic matter in laminated-Bioturbated interbeds from fine-grained marine sequences. Mar Geol 70(1-2):67-84

Rabien A (1956) Zur Stratigraphie und Fazies des Ober-Devons in der Waldecker Hauptmulde, Abh Hess L. Amt Bodenforsch 16:1-83

Schnellbächer P (2007) Hangschuttsedimente einer devonischen Karbonatplattform (Freikofel, Karnische Alpen)-Sedimentfazies und transportmechanismen. Universität Greifswald. Greifswald [unpubl BSc thesis], pp 1-61

Schnellbächer P (2010a) Kartierung des Freikofel in den Karnischen Alpen. Bericht zur Masterkartierung, Universität Greifswald. Greifswald [unpubl mapping report], pp 1-41

Schnellbächer P (2010b) Stratigraphy, transport mechanisms and provenience of Devonian carbonate slope deposits (Freikofel, Carnic Alps). Universität Greifswald. Greifswald. [unpubl. master thesis], pp 1-124

Schönlaub HP (1971) Die fazielle Entwicklung im Altpaläozoikum und Unterkarbon der Karnischen Alpen. Zeitschrift der Deutschen Geologischen Gesellschaft 122:97-111

Schönlaub HP (1979) Das Paläozoikum in Österreich. Abh Geol B A 33:1-124

Schönlaub HP (1980) Carnic Alps. Field trip A. With contributions from Jaeger H, House MR, Price JD, Göddertz B, Priewalder H, Walliser OH, Kř́rž J, Haas W, Vai GB. In: Schönlaub HP (ed) Second European conodont symposium, ECOS II, guidebook, abstracts. Abh Geol B A 35:5-57

Schönlaub HP (1985) Das Paläozoikum der Karnischen Alpen. In: Daurer A, Schönlaub HP (eds) Arbeitstagung der Geologischen Bundesanstalt 1985 in Kötschach-Mauthen. Geol Bundesanstalt, Wien, p 87

Schönlaub HP (1991) Vom Urknall zum Gailtal-500 Millionen Jahre Erdgeschichte in der Karnischen Region. Geol Bundesanstalt, Wien, p 169

Schönlaub HP (1992) Stratigraphy, biogeography and paleoclimatology of the Alpine Paleozoic and its implications for plate movements. Jb Geol B A 135(1):381-418

Schönlaub HP, Histon K (2000) The Palaeozoic evolution of the southern Alps. Mitt Österr Geol Ges 92:15-34

Schönlaub HP, Histon K, Pohler S (2004) The palaeozoic of the Carnic Alps. In: Schönlaub, HP (ed) Field trip Carnic Alps guidebook, 23-24 June 2004, Carinthia Austria. Geol Bundesanstalt 40 , pp 2-32

Scotese C (2002) The Paleomap Project. http://www.scotese.com/

Sepkoski JJ Jr (1995) Patterns of Phanerozoic extinctions: a perspective from global data bases. In: Walliser $\mathrm{OH}(\mathrm{ed})$ Global events and event stratigraphy. Springer, Berlin, pp 35-51
Sliwinsky G, Whalen MT (2010) Trace element variations in the middle Frasnian punctata zone (Late Devonian) in the western Canada sedimentary basin-changes in ocean bioproductivity and paleoredox spurred by a pulse of terrestrial afforestation? Geol Belg 13(4):459-482

Spalletta C, Perri MC (1998) Stop 2.1B-Givetian and Frasnian conodonts from the Pramosio 327 section (Carnic Alps, Italy). In: Perri MC, Spalletta C (eds) Southern Apls field trip guidebook. Seventh international conodont symposium held in Europe. Giorn di Geol s3 60 (spec issue), pp 190-197

Spalletta C, Vai GB (1984) Upper Devonian intraclast parabreccias interpreted as seismites. Mar Geol 55:133-144

Spalletta C, Vai GB, Venturini C (1980) Il Flysch ercinico nella geologia dei Monti Paularo e Dimon (Alpi Carniche). Mem Soc Geol It 20:243-265

Spalletta C, Perri MC, Vai GB (1983) Pattern of conodont reworking in the Upper Devonian of the Alps: palaeoenvironmental and palaeotectonic implications. Lethaia 16(1):51-66

Suttner TJ (2007) Conodont stratigraphy, facies-related distribution patterns and stable isotopes (carbon and oxygen) of the uppermost Silurian to Lower Devonian Seewarte Section (Carnic Alps, Carinthia, Austria). Abh Geol B A 59:1-111

Stark A (2007) Hangschuttsedimente einer devonischen Karbonatplattform-Conodonten-stratigraphie (Freikofel, Karnische Alpen)—Universität Greifswald. Greifswald [unpublished BSc thesis], pp 1-70

Stow DAV, Shanmugam G (1980) Sequence of structures in finegrained turbidites: comparison of recent deep-sea and ancient flysch sediments. Sediment Geol 25(1-2):23-42

Tucker ME (1973) Sedimentology and diagenesis of Devonian pelagic limestones (Cephalopodenkalk) and associated sediments of the Rhenohercynian Geosyncline, West Germany. N Jb Geol Paläont Abh 142:320-350

Vai GB (1975) Hercynian basin evolution of the Southern Alps. Geology of Italy, ESSLA R II:293-298

Vai GB (1976) Stratigrafia e paleogeografia ercinica delle Alpi. Mem Soc Geol Italy 13:7-37

Vai GB (1980) Sedimentary environment of Devonian pelagic limestones in the Southern Alps. Lethaia 13(1):79-91

Vai GB (1998) Field trip through the Southern Alps: an introduction with geological settings, palaeogeography and Palaeozoic stratigraphy. In: Perri MC, Spalletta C (eds) Southern Alps field trip guidebook. Seventh international conodont symposium held in Europe. Giorn di Geol s3 60(3)(spec issue), pp 1-38

Venturini C (1990) Geologia delle Alpi Carniche centro-orientali. Comune di Udine 36:1-220

Venturini C, Spalletta C, Vai GB, Pondrelli M, Delzotto S, Fontana C, Longo Salvador G, Carulli GB (2009) Note illustrative del foglio 031 Ampezzo, Carta geologica d'Italia alla scala 1:50000; ISPRA (ex-APAT, Servizio Geologico d'Italia), pp 7-232

von Gaertner HR (1931) Geologie der Zentralkarnischen Alpen. Denkschrift der Österreichischen Akademie der Wissenschaften, mathematisch-naturwissenschaftliche Klasse, Abteilung 102: 113-199

Walliser OH (1964) Conodonten des Silurs. Abh Hess L Amt Bodenforsch 41:1-106

Wendt J, Aigner T (1985) Facies patterns and depositional environments of Palaeozoic cephalopod limestones. Sediment Geol 44(3-4):263-300 